NBER WORKING PAPER SERIES

\title{
CAPITALISTS IN THE TWENTY-FIRST CENTURY
}

\author{
Matthew Smith \\ Danny Yagan \\ Owen M. Zidar \\ Eric Zwick \\ Working Paper 25442 \\ http://www.nber.org/papers/w25442 \\ NATIONAL BUREAU OF ECONOMIC RESEARCH \\ 1050 Massachusetts Avenue \\ Cambridge, MA 02138 \\ January 2019, Revised June 2019
}

This work does not necessarily reflect the views of the US Treasury Department or the National Bureau of Economic Research. We thank Alan Auerbach, Tom Brennan, Jediphi Cabal, Curtis Carlson, Raj Chetty, Steve Cicala, Michael Cooper, Roger Gordon, John Guyton, Bob Hall, Barry Johnson, Greg Kaplan, Steve Kaplan, Henrik Kleven, Pat Kline, Adam Looney, Jay MacKie, John McClelland, Kevin Murphy, Neale Mahoney, James Pearce, Jim Poterba, Rich Prisinzano, Emmanuel Saez, Jesse Shapiro, David Splinter, Larry Summers, Mike Weber, Matt Weinzierl, Gabriel Zucman, and anonymous referees as well as seminar and conference participants for helpful conversations on this draft. We thank Tom Cui, Katie Donnelly Moran, Clancy Green, Sam Karlin, Stephanie Kestelman, Carl McPherson, Francesco Ruggieri, Karthik Srinivasan, John Wieselthier, and Caleb Wroblewski for excellent research assistance. Yagan gratefully acknowledges financial support from the Laura and John Arnold Foundation. Zidar and Zwick gratefully acknowledge financial support from Chicago Booth's Initiative on Global Markets (IGM), the Kauffman Foundation, and the University of Chicago Booth School of Business. Zidar also gratefully acknowledges support from the Kathryn and Grant Swick Faculty Research Fund at the University of Chicago Booth School of Business and National Science Foundation under Grant Number 1752431, and Zwick gratefully acknowledges financial support from the Neubauer Family Foundation, the Polsky Center, and the Hultquist Faculty Research Endowment at the University of Chicago Booth School of Business.

NBER working papers are circulated for discussion and comment purposes. They have not been peer-reviewed or been subject to the review by the NBER Board of Directors that accompanies official NBER publications.

(C) 2019 by Matthew Smith, Danny Yagan, Owen M. Zidar, and Eric Zwick. All rights reserved. Short sections of text, not to exceed two paragraphs, may be quoted without explicit permission provided that full credit, including $(\mathcal{C}$ notice, is given to the source. 
Capitalists in the Twenty-First Century

Matthew Smith, Danny Yagan, Owen M. Zidar, and Eric Zwick

NBER Working Paper No. 25442

January 2019, Revised June 2019

JEL No. D31

\begin{abstract}
$\underline{\text { ABSTRACT }}$
How important is human capital at the top of the U.S. income distribution? A primary source of top income is private "pass-through" business profit, which can include entrepreneurial labor income for tax reasons. This paper asks whether top pass-through profit mostly reflects human capital, defined as all inalienable factors embodied in business owners, rather than financial capital. Tax data linking 11 million firms to their owners show that top pass-through profit accrues to working-age owners of closely-held, mid-market firms in skill-intensive industries. Pass-through profit falls by three-quarters after owner retirement or premature death. Classifying three-quarters of pass-through profit as human capital income, we find that the typical top earner derives most of her income from human capital, not financial capital. Growth in pass-through profit is explained by both rising productivity and a rising share of value added accruing to owners.
\end{abstract}

Matthew Smith

Office of Tax Analysis

U.S. Department of the Treasury 1500 Pennsylvania Avenue, NW

Washington, D.C. 20220

matthew.smith@treasury.gov

Danny Yagan

Department of Economics

University of California, Berkeley

530 Evans Hall, \#3880

Berkeley, CA 94720

and NBER

yagan@berkeley.edu
Owen M. Zidar

Department of Economics \&

Woodrow Wilson School

Princeton University

237 Julis Romo Rabinowitz Building

Princeton, NJ 08544

and NBER

ozidar@princeton.edu

Eric Zwick

Booth School of Business

University of Chicago

5807 South Woodlawn Avenue

Chicago, IL 60637

and NBER

ezwick@chicagobooth.edu 
[The human capital hypothesis] is far less consequential than one might imagine. ... "non-human" capital seems almost as indispensable in the twenty-first century as it was in the eighteenth or nineteenth, and there is no reason why it may not become even more so. — Thomas PiketTy (2014)

In the last few decades of the twentieth century, the primary driver of rising top incomes was wage income growth (Piketty and Saez, 2003). Since then, rising capital income has shifted focus to the role of capital and financial wealth (Piketty, Saez and Zucman, 2018). ${ }^{1}$ Understanding the nature of top incomes is essential for explaining their evolution and assessing policy implications. Are America's top earners financial-capital rich-those who derive most of their income from non-human capital-or are they human-capital richentrepreneurs and wage earners who derive most of their income from their human capital?

This paper uses de-identified administrative tax data to characterize top incomes and their rise in the twenty-first century. Throughout the paper, we measure income using both directly observed fiscal income from tax returns following Piketty and Saez (2003) and imputed national income following Piketty, Saez and Zucman (2018) (henceforth PSZ). ${ }^{2}$ We first establish how much top earners make from three broad sources: wage income, business income, and other capital income such as interest and rent payments. In 2014, most income at the very top is non-wage income, the primary source of which is business income.

Most top business income comes from private "pass-through" businesses that are not taxed at the entity level; instead, income passes through to the owners who pay taxes on their share of the firm's income. This feature allows us to build a new dataset linking pass-through firms (S-corporations and partnerships, defined below) to their owners for 11 million firms between 2001 and 2014. This dataset enables us to ask whether top pass-through income should primarily be thought of as human capital income accruing to entrepreneurs or as financial capital income accruing to investors. We define human capital broadly to refer to all inalienable factors embodied in business owners, including labor supply, networks, reputation, and rent-extraction ability. Overall, we find that top earners are predominantly human-capital rich rather than financial-capital rich, and that $53 \%$ of top $1 \%$ income accrues to the human capital of these wage earners and entrepreneurs.

The first part of the paper describes who earns business income and the salient features

\footnotetext{
${ }^{1}$ Piketty (2014) analyzes how capital accumulation can lead to increasing inequality. Karabarbounis and Neiman (2014) document rising capital shares. Saez and Zucman (2016) use capitalized income flows to show that wealth concentration in the U.S. has been increasing, in contrast to the flat path of wealth concentration based on estate tax returns in Kopczuk and Saez (2004). Piketty and Zucman (2014) document rising capitaloutput ratios. Rognlie (2016) and Caballero, Farhi and Gourinchas (2017) discuss interpretations.

${ }^{2}$ Fiscal income equals total tax return income minus realized capital gains and is measured at the household level. Imputed national income ("Distributional National Accounts") includes additional imputed components of national income and is measured at the individual level. Section 1 contains more detail.
} 
of their firms. The data reveal a striking world of business owners who prevail at the top of the income distribution. Most top earners are pass-through business owners. In 2014, over $69 \%$ of the top $1 \%$ and over $84 \%$ of the top $0.1 \%$ earn some pass-through business income. In absolute terms, that amounts to over $1.1 \mathrm{M}$ pass-through owners with fiscal income over $\$ 390 \mathrm{~K}$ and 140,000 pass-through owners with fiscal income over $\$ 1.6 \mathrm{M}$. In both number and aggregate income, these groups far surpass that of top public company executives, who have been the focus of much inequality commentary (see Edmans and Gabaix (2016) for a survey). Typical firms owned by the top 1-0.1\% are single-establishment firms in professional services (e.g., consultants, lawyers, specialty tradespeople) or health services (e.g., physicians, dentists). A typical firm owned by the top $0.1 \%$ is a regional business with $\$ 20 \mathrm{M}$ in sales and 100 employees, such as an auto dealer, beverage distributor, or a large law firm.

Most pass-through business income accrues to undiversified, working-age owners of midmarket firms in skill-intensive industries. Specifically, an individual's pass-through income typically derives from one firm with one to three owners and amounts to a large share of her total income. The age distribution of these owners closely mirrors that of high-income wage earners; in contrast, the owners of more passive forms of capital skew much older. Most pass-through business income derives from firms with $\$ 5 \mathrm{M}$ to $\$ 500 \mathrm{M}$ in sales operating across diverse geographies and sectors. Despite this diversity, most profits are earned in relatively labor-intensive industries, especially in those that demand skilled labor. In contrast, nonpass-through businesses (C-corporations) are more prevalent in manufacturing and capitalintensive industries, with profits concentrated among firms with more than $\$ 500 \mathrm{M}$ in sales. Together, these facts support the notion that most top pass-through earners are humancapital rich.

The second part of the paper uses quasi-experimental event studies to quantify the extent to which pass-through profits reflect returns to owner human capital rather than to nonhuman financial capital. The ideal experiment would be to measure the profit impact of exogenously forcing pass-through owners to withdraw their human capital from their firms. We approximate this ideal with two natural experiments: one measures the profit impact of owner deaths and another measures the profit impact of owner retirements.

In the first natural experiment, we identify non-elderly owners who died 2005-2010 and who earned over one million dollars in the year before their death. We then match their firms to similar counterfactual firms that did not experience an owner death. Profits at owner-death firms track counterfactual firms closely in the pre-period then fall immediately and persistently upon owner death. The effect is an $82 \%$ decline in firm profits.

In the second natural experiment, we study the event of owner retirement, inferred when 
the firm transitions from four straight years of paying at least one owner W-2 wages to two years of paying no owner wages. The presumption is that these owners replace themselves with non-owner managers whose compensation is entirely reported as wages and bonuses, not profits. Profits at owner-retirement firms track counterfactual firms closely in the pre-period then fall immediately and persistently upon owner retirement. The effect is an $83 \%$ decline in firm profits. Our baseline specification is equal weighted. Dollar-weighted approaches deliver similar estimates, although the standard errors do increase with dollar-weighting. Averaging our estimates across top $1 \%$, million-dollar-earner, and top $0.1 \%$ groups, we conclude that approximately three-quarters of top pass-through profits are returns to owner human capital.

Pass-through owners have a tax incentive to receive their compensation as profits rather than wages and bonuses, while owners of traditional C-corporations do not. We find that firms that switch from C-corporation form to pass-through form reduce wage bills and increase profits. This result provides evidence consistent with a tax explanation of pass-through profits reflecting returns to owner human capital.

We use our three-quarters estimate for the labor (human capital) share of pass-through income to conduct a person-level analysis of top earners. Is the typical top earner a human capitalist or a financial capitalist? That is, if you run into a very high earner on the street, does she likely earn most of her income from labor income or from capital income? When ignoring pass-through income, a minority of top earners are human-capital rich. However, when defining labor income as wages plus three-quarters of pass-through income, this assessment reverses: most top earners are human-capital rich, not financial-capital rich. For example, among million-dollar earners in imputed national income, $67 \%$ derive most of their income from labor income but only 35\% derive most of their income from wages alone. Hence, the human capital component of pass-through income transforms one's view of the typical top earner.

Some individuals with wage and pass-through income may provide little human capital services, perhaps drawing a salary or ownership share from a family firm as a way to avoid estate taxes. To address this consideration, we use the parent-child links of Chetty, Friedman, Saez, Turner and Yagan (2019) to classify whether individuals aged 32-34 are "self-made," which we conservatively define as top earners whose parents were not in the top $1 \%$. These individuals are unlikely to receive large financial inheritances or inter vivos gifts. We find that more than $75 \%$ of top earners in the parent-linked sample are self-made.

We also use our three-quarters estimate to conduct a novel aggregate analysis of top income. How much is labor income? How much is entrepreneurial income (pass-through income plus W-2 wages paid to owners)? And how do these amounts compare to other income components? While dollar-level aggregates are more uncertain, two findings stand 
out. First, holding other assumptions constant, our classification of three-quarters of passthrough income as labor income reduces the top capital share in imputed national income by eight percentage points from $55 \%$ to $47 \% .^{3}$ Second, top entrepreneurial income and its human capital component are large. In every top income group and income definition, entrepreneurial income rivals or exceeds both non-owner wage income and non-pass-through capital income. The human capital component of entrepreneurial income itself exceeds top public equity income.

To complement our cross-sectional analysis of top incomes, we conclude by investigating the evolution of top entrepreneurial income, which has risen substantially over time. We use our linked firm-owner-worker data to decompose the growth of top entrepreneurial income and shed light on how it has increased since 2001. Approximately 30\% of the growth in entrepreneurial income reflects businesses reorganizing from C-corporation to pass-through form. Adjusting for this fact, we find no role for a larger workforce in driving higher entrepreneurial income. Instead, both labor productivity and a rising share of value added accruing to owners account for the growth of top entrepreneurial income. Thus, explaining the rise of top entrepreneurial income requires both a growing pie and an expanding owner-manager slice.

This study's main contribution is to the income inequality literature. Piketty and Saez (2003) use fiscal income to show that labor drove the rise in top incomes in the second half of the twentieth century. PSZ use imputed national income to find that capital has been driving the rise since 2000 in top income and now exceeds labor income at the top. An innovation of our paper relative to past work is that we use microdata to ask person-level in addition to dollar-level questions. PSZ's focus is a dollar-level analysis of top incomes, but their findings raise the possibility that the financial-capital rich have displaced the human-capital rich as the typical top earner. ${ }^{4}$ However, we find that the typical top earner is human-capital rich. This finding depends crucially on how one treats top pass-through income - a large component of top "capital" income and 30 to $40 \%$ of top $1 \%$ income. We classify $75 \%$ of pass-through income as human capital income. In contrast, PSZ assume a labor share of 0\% for one type of pass-through income (S-corporation) and $70 \%$ for the rest (partnership and other pass-through).

\footnotetext{
${ }^{3}$ PSZ's top $1 \%$ capital share is $55 \%$ in Figure VIIIb (based on data in Online Appendix Table TB2f, which they use to discuss our paper in their Online Appendix C.2). PSZ also report an alternative top 1\% capital share of $59 \%$ in Figure VIIIa, which draws on data in Online Appendix Table TB2d that allocates more pension income to capital for top earners.

${ }^{4}$ PSZ occasionally provide person-level interpretations of their results: "[In] the post-World War II decades, most top earners derived their income from assets. From the 1970s and 1990s, the fraction of top earners deriving their income from work grew. This process culminated in $2000 \ldots$ Since then, the capital share has bounced back." (Piketty, Saez, and Zucman, pp.595-597, emphasis added).
} 
Our approach also affects conclusions about the composition of top incomes (i.e., for dollar-level questions). Under our approach, the top 1\% labor share of imputed national income in 2014 increases from $45.4 \%$ in PSZ to $52.9 \%$. Of the 7.6 percentage point change, the S-corporation adjustment contributes 5.3 percentage points, the partnership and other pass-through adjustment contributes 1.2 percentage points, and correcting an inaccurate extrapolation in PSZ contributes 1.1 percentage points. ${ }^{5}$ Applied to the time series, our classification yields qualitatively similar results to PSZ: the top 1\% labor share rose from the 1960s, peaked in 2000, and then returned to 1990 levels.

Our findings draw attention to a class of entrepreneurs hidden from public view who prevail among top earners and whose human capital income is key for understanding top incomes. An important role for human capital is consistent with the view that the demand for top human capital has outpaced its supply, with the returns to top human capital increasingly taking the form of business income. ${ }^{6}$ However, we stress that returns to top owner-managers need not be socially optimal and can include returns to unproductive behavior like rentseeking (Krueger, 1974; Murphy, Shleifer and Vishny, 1991) or returns to elite connections (Fisman, 2001; Khwaja and Mian, 2005; Zimmerman, forthcoming).

For the literature on rising firm profitability, we provide evidence on the relative impact of productivity growth and the distribution of surplus between workers, managers, and owners. Our finding that productivity explains an important part of entrepreneurial income growth aligns with recent work emphasizing the role of efficiency improvements in driving firm profitability (Autor, Dorn, Katz, Patterson and Van Reenen, 2017; De Loecker and Eeckhout, 2017). Entrepreneurial income is also increasing due to a rising share of value added accruing to owners. In our data, the owners appear to be managers and key workers, which contrasts with the separation of ownership and control in public company governance. Thus, our results point to channels other than zero-sum bargaining between executives and corporate boards for rising owner pay. ${ }^{7}$

Our results inform three other literatures. First, a longstanding literature debates the relative importance of inherited wealth versus self-made wealth (Kotlikoff and Summers, 1981; Modigliani, 1986; Piketty, 2011; Piketty, Postel-Vinay and Rosenthal, 2014). We use parent

\footnotetext{
${ }^{5}$ In 2014, top $1 \%$ total income amounts to $\$ 3 \mathrm{~T}$ in imputed national income, so these three adjustments amount to $\$ 162 \mathrm{~B}, \$ 36 \mathrm{~B}$, and $\$ 33 \mathrm{~B}$, respectively. See Section 1 and Online Appendix D for additional discussion.

${ }^{6}$ See Katz and Murphy (1992), Autor, Katz and Kearney (2008), Goldin and Katz (2009), and Murphy and Topel (2016) for some prominent articulations of this view. Kaplan and Rauh (2013) argue that the broad-based rise in top incomes reflects market-driven forces, such as an increased return to skill.

${ }^{7}$ Gabaix and Landier (2008), Piketty, Saez and Stantcheva (2014), and Piketty (2014) highlight the role of bargaining for the growth of top executive pay among public and other companies with delegated management. See Edmans and Gabaix (2016) for a survey of executive pay trends.
} 
income to infer whether individuals are likely self-made. Second, we find that firm-level variation in profitability amplifies measured top income inequality among firm owners, and much of their human capital returns take the form of profits rather than wages. ${ }^{8}$ Third, we contribute to a literature on the impact of taxes on economic measurement, the composition of top incomes, and corporate organization, which we discuss in the conclusion. ${ }^{9}$

Last, we make two methodological contributions that may improve distributional income and wealth estimates. First, we provide an appendix that explores alternative methods for imputing retained earnings to individuals. Second, top wealth estimates based on capitalized income flows and a constant returns assumption can be improved by accounting for the higher profitability of top-owned firms.

The paper is organized as follows. Section 1 describes the institutional background and data. Section 2 documents the importance of pass-through income for top income inequality, and then presents descriptive statistics on the prevalence of top pass-through ownership and the sizes and industries of those businesses. Section 3 presents event studies, which estimate whether and the extent to which pass-through profits reflect the return to owner human capital. Section 4 uses these estimates to characterize top earners as human-capital rich or financial-capital rich, to estimate the share of top earners that are self-made, and to quantify top income shares by income source. Section 5 analyzes the evolution of top entreprenuerial income and the contributions of changing labor productivity, scale, and factor shares. Section 6 concludes.

\section{Institutional Background and Data}

\subsection{How U.S. Businesses Are Organized and Taxed}

There are three major types of formal businesses: C-corporations, S-corporations, and partnerships. All three forms provide limited liability to their owners, but they differ in their ownership rules, tax treatment, and profit measurement. C-corporations and partnerships may be owned by individuals, businesses, non-profits, and foreigners, while S-corporations

\footnotetext{
${ }^{8} \mathrm{An}$ active literature documents firm- and industry-level variation in profitability and links firm performance and wage inequality (Hall, 1988; Foster, Haltiwanger and Syverson, 2008; Hsieh and Klenow, 2009; Syverson, 2011; Abowd, Kramarz and Margolis, 1999; Card, Heining and Kline, 2013; Song, Price, Guvenen, Bloom and von Wachter, forthcoming) as opposed to income inequality, which includes business income. Fagereng, Guiso, Malacrino and Pistaferri (2016) document heterogeneous and persistent returns in Norway, finding a key role for closely held firms at the top of the income distribution.

${ }^{9}$ See, e.g., Gordon and MacKie-Mason (1994), Slemrod (1996), Mackie-Mason and Gordon (1997), Gordon and Slemrod (2000), Alstadsaeter, Jacob, Kopczuk and Telle (2016), Auten and Splinter (2018), DeBacker and Prisinzano (2015), Cooper, McClelland, Pearce, Prisinzano, Sullivan, Yagan, Zidar and Zwick (2016), Clarke and Kopczuk (2017), Prisinzano and Pearce (2017), and Dyrda and Pugsley (2018).
} 
face ownership restrictions. Firms with more than 100 owners, with owners who are not U.S. individuals, or with more than one class of stock cannot be S-corporations. These restrictions bar public companies and corporations with complex ownership structures (such as venture-capital-financed startups) from being S-corporations. Separate restrictions also bar almost all partnerships from being publicly traded. Prominent pass-throughs include the Hobby Lobby corporation, home improvement retailer Menards, Fidelity Investments, and the U.S. arm of PricewaterhouseCoopers.

C-corporations pay the corporate income tax on annual taxable income, and taxable shareholders pay dividend taxes on dividends and pay capital gains taxes on gains realized from selling shares. S-corporations and partnerships, collectively known as pass-through businesses, pay no entity-level tax. Instead, taxable business income "passes through" to shareholders' tax returns where it is taxed as ordinary income in the year it is earned by the firm. When actually distributed to owners, pass-through dividends are untaxed. Since 1986, pass-through income typically enjoys a lower tax burden than C-corporation income. ${ }^{10}$ As a result, most businesses - even those with over $\$ 500$ million in revenue - are now passthroughs and most taxable business income is pass-through income, even though almost no pass-throughs are publicly traded. ${ }^{11}$ Among pass-throughs, S-corporations generate more business income than partnerships.

Finally, organizational forms differ in how owner compensation is reported on tax returns. The wages of S-corporation owners are legally required to be "reasonable" and to reflect the market value of labor services, while profit is supposed to reflect residual earnings. However, in practice, owner-managers enjoy considerable discretion in how their compensation is categorized as wages or profits. Owner-managers of C-corporations enjoy a lower tax burden when paid in wages, but owner-managers of pass-throughs enjoy a lower burden when paid in profit. ${ }^{12}$ See Online Appendix A for additional institutional detail.

\subsection{Data on Top Incomes}

We use two data series on the U.S. income distribution 1962-2014. Piketty, Saez and Zucman (2018) (henceforth PSZ) assembled these data based on stratified random samples of personal

\footnotetext{
${ }^{10}$ In the pre-2018 period we study, pass-throughs were strongly tax-advantaged. The 2017 Tax Cuts and Jobs Act reduced taxes on both pass-throughs and C-corporations. There remains a clear tax preference for pass-throughs in some industries and an ambiguous one in others.

${ }^{11}$ By 2011, 54.2\% of U.S. taxable business income was earned by formal pass-throughs and sole proprietorships (informal businesses also taxed at the owner level) and only $45.8 \%$ by C-corporations (Cooper, McClelland, Pearce, Prisinzano, Sullivan, Yagan, Zidar and Zwick, 2016).

${ }^{12}$ Legal rules mandate that most partnership owner compensation be reported as profits even when compensation for labor supply. Owners of C-corporations avoid dividend taxation when paid in wages. Owners of pass-throughs face no dividend tax and may avoid payroll taxation when paid in profits.
} 
tax returns.

Fiscal income is directly observed income on personal tax returns. We use the main fiscal income definition of Piketty and Saez (2003) (henceforth PS), which measures fiscal income at the level of the tax unit (typically a single adult or a married couple) and equals Form 1040 total income minus realized capital gains, unemployment compensation, and taxable social security benefits. The series includes synthetic records for individuals who do not file income tax returns, thereby reflecting the full U.S. adult population.

Imputed national income ("Distributional National Income" in PSZ, sometimes INI) imputes components of national income not observed in personal tax data such as employerprovided health insurance, rent from owner-occupied housing, and C-corporation retained earnings (i.e., earnings not distributed to owners as dividends). We use PSZ's main definition which measures pre-tax-and-transfer imputed national income at the level of the individual adult and equally splits each income component between spouses. Imputed national income aggregates across individuals to equal national income (GDP minus capital depreciation plus net income received from abroad) in the National Income and Product Accounts. See our Online Appendix C for a comparison of our top pass-through statistics with PSZ's Online Appendix C.2, and Online Appendix D for a quantitively important correction that we make to the published PSZ data. ${ }^{13}$ Note that national income includes unrealized capital gains in the form of corporate retained earnings but not in the form of expectations-induced asset price growth. Integrating such asset price effects into an analysis of inequality is a useful direction for future research.

Our analysis considers top 1\% earners and several interesting subgroups, including milliondollar earners and the top $0.1 \%$. In 2014, the top $1 \%$ and top $0.1 \%$ thresholds in the fiscal income series are $\$ 390 \mathrm{~K}$ and $\$ 1.58 \mathrm{M}$, respectively and in the imputed national income series are $\$ 420 \mathrm{~K}$ and $\$ 1.88 \mathrm{M}$. We add the million-dollar-earner group as a salient midpoint between the top $1 \%$ and top $0.1 \%$ groups.

For each data series, we follow PS and PSZ in defining income sources. Within each series, wages plus business income plus other capital income equals total income. For fiscal income, wage income (sometimes "wages") includes Form 1040 wages, salaries, and tips; pension distributions; and annuities. Pass-through income includes S-corporation income, partnership income, and sole proprietor's income. Entrepreneurial income equals pass-through income plus owner wages, defined in the next subsection. ${ }^{14}$ Business income equals pass-through in-

\footnotetext{
${ }^{13}$ Some exhibits and numbers in the published version of PSZ, including those described in their Online Appendix C.2 that discusses our paper, used an extrapolation for 2011 through 2014 that materially underestimated top pass-through income. We have updated their series based on actual, unextrapolated data.

${ }^{14}$ We follow earlier work (e.g., Piketty and Saez 2003) in including all pass-through income as en-
} 
come plus C-corporation dividends. Other capital income includes interest, rents, royalties, and estate and trust income.

For imputed national income, wages includes Form 1040 wages, salaries, and tips; imputed unreported wage compensation; payroll taxes; imputed nontaxable employee benefits like employer-provided health insurance; a portion of sales and excise taxes; and a portion of pension income. Pass-through income includes S-corporation income, partnership income, sole proprietor's income, imputed unreported income from unincorporated businesses, a portion of sales and excise taxes, and a portion of corporate taxes. Business income equals pass-through income plus C-corporation dividends, imputed C-corporation retained earnings, a portion of sales and excise taxes, and a portion of corporate taxes. Entrepreneurial income equals pass-through income plus owner wages, defined in the next subsection. Other capital income includes interest, imputed underreported interest income, rents, imputed rental income (including imputed rent from owner-occupied housing), a portion of sales and excise taxes, and a portion of pension income. ${ }^{15}$

Both we and PSZ classify wages as labor income (i.e., a return to human capital) and classify other capital income as capital income (i.e., a return to financial or physical capital). An important contribution of our paper is an estimate of the share of pass-through income that is in fact labor income rather than capital income. PSZ assume that $0 \%$ of S-corporation income is labor income and that $70 \%$ of the remainder of pass-through income is labor income. We estimate below that $75 \%$ is labor income. ${ }^{16}$

We present our income distribution findings in both fiscal income and imputed national income. Fiscal income has the advantage of being directly observed on personal income tax returns, but has the disadvantage of understating top capital income because some components do not appear on personal tax returns. Imputed national income has the advantage that it sums to national income, but has the disadvantage of relying on imputation assump-

trepreneurial income, even though some pass-through income accrues to non-founders. Note that hedge fund and private equity pass-throughs earn much income in the form of dividends, retained earnings, interest, and rental income. Such income retains its character as it flows through pass-through firms and is classified as either C-corporation income or other capital income, not pass-through income which is exclusively an operating profit concept.

${ }^{15}$ With reference to PSZ's top incomes decomposition (their Online Appendix Table TB2f), wages equals Compensation of Employees plus Labor Component of Pension Income. Pass-through income equals Scorporation Dividends plus the Capital and Labor Components of Mixed Income. Business income equals pass-through income plus C-corporation Dividends plus C-corporation Retained Earnings. Other capital income equals Interest and Rents plus Capital Component of Pension Income.

${ }^{16}$ More specifically, PSZ assume that $70 \%$ of the remainder of pass-through income is labor income, but tax adjustments under the assumption that business capital bears $100 \%$ of the non-housing capital tax yields a final tax-inclusive labor share of approximately $65 \%$ in recent years (see their Figure VIIIb and Online Appendix Tables TB2b and TB2f). Following their assumptions but using a $75 \%$ pretax labor share yields a tax-inclusive labor share of $70 \%$ in our imputed national income analysis. 
tions. PSZ employ several assumptions to impute missing national income to individual adults - a path-breaking prototype to which they encourage ongoing refinement. Relevant to our analysis, we believe the available evidence suggests that imputed national income may overstate top capital income. These competing considerations motivate the presentation of our findings in both series, likely (in our view) bounding the truth. Our qualitative results hold in both series.

Top capital income in imputed national income may be overstated because of the following consideration regarding C-corporation retained earnings. When a C-corporation distributes less in dividends than it makes in after-tax income, it retains earnings within the firm. ${ }^{17}$ Those retained earnings ( $\$ 649 \mathrm{~B}$ in 2014) are a substantial part of national income but do not appear on personal tax returns and thus are not in fiscal income. PSZ allocate the household share of aggregate retained earnings to individuals in proportion to the sum of the individual's observed dividends and realized capital gains. The rationale is that when C-corporation income does appear on personal tax returns, it appears as either dividends or realized capital gains. However, published IRS reports indicate that at least $25 \%$ and as much as $75 \%$ of realized capital gains are not from the sale of C-corporate stock and are instead gains from real estate and other asset sales or carried interest. This fact can explain how total realized capital gains ( $\$ 732 \mathrm{~B}$ in 2014 ) vastly exceeds the total household share of retained earnings (\$306B in 2014). Realized capital gains are much larger than dividends and much more concentrated among top earners. Hence, imputing retained earnings in proportion to each individual's sum of dividends and $100 \%$ of realized capital gains may allocate too much retained earnings to top earners and not enough to lower earners. ${ }^{18}$ See Online Appendix $\mathrm{E}$ for a full discussion and Online Appendix $\mathrm{F}$ for retained earnings imputations under alternative assumptions. ${ }^{19}$

\subsection{Data on Firms Linked to Owners and Workers}

We construct a novel dataset on the universe of S-corporations and partnerships linked to owners and workers using de-identified data from income tax records spanning 2001-2014.

\footnotetext{
${ }^{17}$ Pass-throughs are measured as having no retained earnings, with effectively $100 \%$ dividends.

${ }^{18}$ Saez and Zucman (2016) conduct a related analysis and report wealth estimates using dividends only. Relative to using dividends alone, their Tables B35 and B37 imply that imputing wealth using dividends and $100 \%$ of realized capital gains increases 2012 top $0.1 \%$ equity wealth by $28 \%$. This adjustment modestly increases total top $0.1 \%$ wealth, which is the primary focus of Saez and Zucman (2016), by 9.2\% (p. 535).

${ }^{19}$ It is valuable to note that all imputations have imperfections. For example, imputations of retained earnings based on observed dividends and realized capital gains allocate too little to concentrated owners of C-corporation stock that pay no dividends and are not sold and therefore too much to other owners. Direct links of C-corporations to their owners would improve measurement, as in Norway (Alstadsaeter, Jacob, Kopczuk and Telle, 2016).
} 
Unlike the top incomes data, these data are available on the full population. We construct these linked firm-owner-worker data as follows.

We first merge the population of firm-level S-corporation business income tax returns (Form 1120S) to the population of S-corporation information returns (Form 1120S, Schedule $\mathrm{K}-1$ ) that link the firms to their owners. ${ }^{20}$ We merge the $1120 \mathrm{~S}$ records onto the K-1 records by masked EIN to yield linked firm-owner data. We follow similar steps to construct the partnership linkage to owners. Specifically, we merge the population of firm-level partnership business income tax returns (Form 1065) to the population of partnership information returns (Form 1065, Schedule K-1). Unlike S-corporations, partnerships can be owned by business entities and by non-U.S. individuals. We focus on direct partnership-owner links in which the partner is a U.S. individual.

Then, for both S-corporations and partnerships, we further merge on information about the owners and workers. We use Form 1040 to merge on each owner's fiscal income. We use data from W-2 forms to measure owner wages - W-2 wage payments from S-corporations and partnerships to individual owners - and to calculate firm-level aggregates of the total number of employees. We merge owner wages onto our top incomes data as mentioned in the previous subsection. ${ }^{21}$

The full sample comprises 158.8M firm-owner-year observations (71.8M S-corporationowner-year observations and 87.0M partnership-owner-year observations) on 11.1M firms with positive sales (7.3M S-corporations and 3.9M partnerships) and with $22.6 \mathrm{M}$ owners (9.8M S-corporation owners and 12.8M partnership owners). In 2014, the sample comprises 10.3M firm-owner-year observations (4.9M S-corporation-owner-year observations and 5.4M partnership-owner-year observations) on 5.0M firms with positive sales (3.7M S-corporations and $1.4 \mathrm{M}$ partnerships) and with $10.3 \mathrm{M}$ owners (4.9M S-corporation owners and 5.4M partnership owners).

No data source systematically links C-corporations to their owners. To compare passthrough activity to C-corporation activity, we supplement the linked data with the Statistics of Income (SOI) sample of corporate income tax returns from 1980-2014. ${ }^{22}$ Together, these

\footnotetext{
${ }^{20}$ These information returns list each owner's share of the corporation's income. S-corporations are required to submit to the IRS a K-1 on behalf of each owner of the S-corporation when the corporation submits its Form 1120S business income tax return. Each owner receives a copy of her K-1, which she uses to report S-corporation income on her Form 1040, Schedule E, and compute her tax liability. Each 1120S includes the firm's masked Employer Identification Number (EIN), and each K-1 includes the firm's masked EIN as well as the owner's masked Social Security Number (SSN).

${ }^{21}$ Some firms deduct wages from their business tax returns but cannot be linked to any W-2s, for example because they use a different employer identification number to file taxes and pay workers. We therefore impute missing owner wages using the owner wages share of individual wages of similar firms' owners. This imputation is minor and used only for Figure 8 below. See Online Appendix B for details.

${ }^{22}$ See Yagan (2015) and Zwick and Mahon (2017) for detail on these weighted, stratified random samples.
} 
data provide a comprehensive account of the major forms of business activity in the United States. Online Appendix B provides further variable definitions.

\section{Business Income and Top Income Inequality}

This section shows that business income is the most important source of income at the top of the income distribution. Most top business income is pass-through income. We then describe who earns pass-through income and the salient features of their firms: most pass-through income accrues to working-age owners of mid-market firms in relatively skill-intensive industries. These descriptive facts are consistent with pass-through income reflecting the returns to human capital.

\subsection{The Sources of Top Income}

How much do top earners make from wage income, business income, and other capital income? Figure 1A plots the share of top earners in each income bin who earn the majority of their income from each source. Figure 1B plots the share of aggregate income from each source. Three patterns emerge. First, from the $90^{t h}$ to the $99^{t h}$ percentile of the income distribution, wage income dominates business and other capital income. At the $90^{\text {th }}$ percentile of the income distribution, over four out of five people earn mostly wage income. Wage income represents over 75 cents of every dollar earned by those at the $90^{\text {th }}$ percentile of the income distribution. Second, business income is much more prevalent higher up in the income distribution. At the very top of the income distribution, wage income falls to $40 \%$ of fiscal income (19\% of INI) and business income accounts for $48 \%$ of fiscal income (56\% of INI). Third, other capital income is less important and amounts to $12 \%$ to $25 \%$ of income at the very top. Fewer than one in six people in the $99.9^{t h}$ percentile derive most of their income from interest, rents, and other capital income. Thus, at both the person-level and dollar-level and regardless of income definition, the main source of income at the very top of the income distribution is business income.

Figure 1C decomposes the business income series into contributions from pass-through business and C-corporation income. Both components' share of income rises with income rank, however pass-through income is more important than C-corporation income throughout the distribution. At the top, pass-through income alone represents nearly forty percent of total income and rivals or exceeds the size of wage income.

The importance of business income from C-corporations differs between fiscal income, which only measures C-corporation dividends, and imputed national income, which includes 
both dividends and PSZ's imputation of retained earnings. In fiscal income, 9.1\% of top income comes from C-corporation dividends, whereas in imputed national income, $22.6 \%$ comes from C-corporation dividends and retained earnings. We show that all key results below hold under both income measures.

Quantifying top retained earnings inherently presents considerable uncertainty as direct ownership data for C-corporations is unavailable and estimates are sensitive to imputation assumptions. Online Appendix F explores PSZ's method and alternative assumptions for allocating retained earnings. Regardless of the income measure, these facts indicate that understanding the nature of business income - and especially the pass-through sector - is imperative for understanding top incomes.

\subsection{The Prevalence and Nature of Top Pass-through Ownership}

Figure 2A demonstrates that pass-through income is prevalent within the top 1\% in 2014 . For example, among the top $0.1 \%, 84 \%$ earn pass-through income. That is 139,000 taxpayers, with aggregate pass-through income of $\$ 264 \mathrm{~B} .{ }^{23}$ For comparison, in Execucomp in 2014, the top 10,700 executives working at the S\&P 1500 earned a combined $\$ 33 \mathrm{~B}$. The scale of top pass-through income far surpasses that of top CEOs, who have been the focus of much inequality commentary.

Figure 2B compares the age distributions of million-dollar earners who differ in the majority source of their income. Most top earners whose primary income source is wage income are between 40 and 59 and very few top workers are older than 70 . This distribution contrasts with the much older distribution of top earners whose primary income source is other capital income. Fifty-six percent of the latter group are older than 60, and nearly $30 \%$ are older than 70 . The age distribution of pass-through owners is much younger $-28 \%$ are older than 60 and only $7 \%$ are older than 70 - and nearly identical to the distribution of top laborers. The population of pass-through owners does not include very many old people or children, whom one might associate with estates and inherited wealth. C-corporation dividends skew much older, distributed more similarly to the other capital earners. Overall, pass-through owners resemble workers, while C-corporation owners resemble other capital earners. ${ }^{24}$ The age distributions are consistent with top pass-through earners being human-capital rich.

\footnotetext{
${ }^{23}$ Among the top 1\%, 69\% earn pass-through income. That is 1,140,000 taxpayers, with aggregate passthrough income of $\$ 476 \mathrm{~B}$. Among the top $0.01 \%, 90 \%$ earn pass-through income. That is 15,000 taxpayers, with aggregate pass-through income of $\$ 116 \mathrm{~B}$. Pass-through prevalence is even higher in imputed national income, not shown in Figure 2.

${ }^{24}$ Appendix Figure I.2 shows similar results for the top 1\% and top $0.1 \%$.
} 


\subsection{Firm Size and Ownership Varies by Organizational Form}

Table 1 provides summary statistics from our linked firm-owner-worker data, restricted to firms with positive sales and non-zero profits. Panel A presents statistics on distinct firm-year observations, and Panel B presents statistics on distinct owner-year observations.

In the 2001-2014 pooled sample of all pass-throughs, the average firm earned $\$ 31 \mathrm{~K}$ in profits on sales of $\$ 1.8 \mathrm{M}$ in 2014 dollars, employed 13 workers, and had 2.3 owners. Passthroughs that have at least one top $0.1 \%$ owner are much larger and more profitable - these firms earned $\$ 1.6 \mathrm{M}$ in profits on $\$ 17.5 \mathrm{M}$ in sales with 74 employees - yet they typically remain closely held, with the median firm having 2 owners. The average number of owners is skewed by a few partnerships (e.g., a large law firm or consultancy) with many owners: when restricting focus to S-corporations, the average number of owners of top $0.1 \%$-owned firms is $3.4 .^{25}$

Pass-through businesses are not only closely held but also undiversified: most top owners own just one firm. If pass-through owners were only contributing financial capital, one might expect them to hold portfolios with shares of many firms. However, the data suggest this strategy is uncommon. Moreover, nearly all owners report being active, i.e., materially participating in the business. For example, the share of top $0.1 \%$ owners who report earning only passive income from their pass-throughs is $7 \%{ }^{26}$

Most top-owned pass-through businesses are mid-market in size. Figure 3A explores the firm size distribution among top-owned pass-throughs and compares it to the distribution for all C-corporations. The profit distributions are markedly different across corporate forms. Eighty percent of the pass-through income for million-dollar earners derives from firms with between $\$ 1 \mathrm{M}$ and $\$ 500 \mathrm{M}$ in sales. Moreover, $72 \%$ of top- $1 \%$ owned pass-through profits come from firms with less than $\$ 50 \mathrm{M}$ in profits. In contrast, the distribution of $\mathrm{C}$-corporations has substantially more concentration in the right tail. Ninety-six percent of C-corporation profits in 2014 come from firms with more than $\$ 500 \mathrm{M}$ in sales. Only $19 \%$ of millionaire-owned pass-through profits come from firms in this size bin.

The characteristics of pass-throughs - closely held, undiversified in ownership, and midmarket in size - supports a narrative of top pass-through income that differs from those for C-corporation income. The C-corporation profit distribution is so skewed that diffuse ownership can nevertheless yield significant income to individual owners. In contrast, passthrough owners tend to earn high incomes via concentrated ownership of one mid-market firm. The pass-through narrative is consistent with active owner-management.

\footnotetext{
${ }^{25}$ Appendix Tables J.1 and J.2 show summary statistics separately for S-corporations and partnerships.

${ }^{26}$ However, as we describe in Online Appendix B, there is a tax incentive to report oneself as being active rather than passive.
} 
An alternative narrative of top incomes emphasizes how managers set their pay by bargaining with a corporate board that represents diffuse shareholders. This story also does not resonate for explaining pass-through income. Pass-throughs have concentrated ownership, which minimizes principal-agent failures - especially if the CEO is a majority owner. Agency explanations may account for more of the growth in CEO and top manager compensation for public companies, which have thousands of owners.

\subsection{The Industry Composition of Business Income}

Figure 3B compares the distributions of total profits across 1-digit NAICS sectors for passthrough firms owned by million-dollar earners to the distributions of C-corporation profits and of all workers from the Current Population Survey. ${ }^{27}$ Top pass-through profits are earned broadly across sectors and are similarly distributed as the overall distribution of workers, relative to C-corporations. ${ }^{28}$ Compared to C-corporation profits, pass-through profits are underrepresented in manufacturing and overrepresented in information, professional services, and health care. Less than $20 \%$ of top pass-through profits are earned in finance.

Table 2 presents a more granular analysis of the industry composition of business income at the 4-digit NAICS level. The left panel lists the top 30 industries in aggregate profits earned by million-dollar-owned pass-through firms, along with the aggregate flow of 2014 profits apportioned pro rata to owners. For each industry, we compare the top pass-through flow to the flow of C-corporation profits and industry-level profits rank within the C-corporation sector. The right panel repeats this exercise for the top 30 industries in aggregate profits earned by C-corporations.

White-collar, skilled service industries dominate the pass-through sector, whereas more capital-intensive industries, especially manufacturing, dominate the C-corporation sector. The five largest industries for millionaire-owned pass-through profits are legal services $(\$ 28.6 \mathrm{~B})$, other financial investment activity $(\$ 28.2 \mathrm{~B})$, other professional and technical services $(\$ 8.2 \mathrm{~B})$, offices of physicians $(\$ 8.0 \mathrm{~B})$, and auto dealers $(\$ 6.7 \mathrm{~B})$. The five largest industries for Ccorporation profits are petroleum and coal product manufacturing $(\$ 98.7 \mathrm{~B})$, pharmaceutical manufacturing $(\$ 63.3 \mathrm{~B})$, nondepository credit intermediation $(\$ 46.6 \mathrm{~B})$, other telecommuni-

\footnotetext{
${ }^{27}$ We divide the service sector 5 into two subsectors: finance, insurance, and real estate (FIRE); and information and professional services. In this section, we exclude firms in the residual category NAICS 5511 (Management of Companies and Enterprises). The category refers to firms that often own related but formally distinct non-financial firms. Among public companies for example, General Electric classifies its industry as a holding company (based on public 10-K financial filings).

${ }^{28}$ Appendix Figure I.5 compares the distribution of state population to the distributions across states of total profits of top-owned pass-throughs and all C-corporations. Pass-through profits are broadly distributed and comparable to the population distribution.
} 
cations $(\$ 35.3 \mathrm{~B})$, and computer and peripheral equipment manufacturing $(\$ 33.3 \mathrm{~B}){ }^{29}$

The C-corporation sector includes many well-known listed companies, which are broadly held both within the household sector and by pensions, non-profits, and foreign investors. In some industries, such as restaurants, retailers, and wholesalers, firms operate in both pass-through and C-corporation form (e.g., Menards versus Home Depot (Yagan, 2015)). Remarkably, certain industries that are prevalent and large for pass-through profits, such as law firms, doctors, and consultants, have negative or nearly zero aggregate profits in the C-corporation sector.

Table 3 presents a disaggregated analysis of pass-through profits for the top industries in the S-corporation and partnership sectors. We define top industries by the 2014 level of profits flowing to either top $1-0.1 \%$ or top $0.1 \%$ owners. This focus on the industries of top-owned firms complements Bakija, Cole and Heim (2012), who study the occupations of top earners using personal income tax returns and find a large role for professional services, finance, and closely held business.

Top pass-through profits comprise human-capital-intensive service professions and to a lesser extent non-manufacturing industries that depend on financial and physical capital, such as real estate and oil and gas. Typical firms owned by the top $1-0.1 \%$ are singleestablishment firms in professional services (e.g., consultants, lawyers, specialty tradespeople) or health services (e.g., physicians, dentists). For example, in the top 1-0.1\%, the largest S-corporation industry is offices of physicians $(\$ 9.1 \mathrm{~B})$ and the largest partnership industry is legal services $(\$ 21.3 \mathrm{~B})$. A typical firm owned by the top $0.1 \%$ might be a regional business with $\$ 20 \mathrm{M}$ in sales and 100 employees, such as an auto dealer, beverage distributor, or a large law firm. There is significant overlap between top S-corporations and top partnerships. However, partnership profits are more concentrated and skew more toward certain high-skilled services, especially legal services and other financial investment activity, which includes private equity, venture capital, and hedge funds. ${ }^{30}$ Overall, most top pass-through businesses do not operate in finance and instead actively produce goods or services across diverse industries. ${ }^{31}$

\footnotetext{
${ }^{29}$ In recent years, the aggregate composition of business income is roughly evenly split between the passthrough and C-corporation sectors (Cooper, McClelland, Pearce, Prisinzano, Sullivan, Yagan, Zidar and Zwick, 2016). Adjusting the C-corporation profit figures for the share of C-corporation wealth owned by the household sector (equal to $\$ 11 \mathrm{~T} / \$ 23.4 \mathrm{~T}=47 \%$ ) and the top $1 \%$ share of C-corporation dividends (49\% in 2014), top 1\% pass-through profits are roughly double the size of top 1\% C-corporation profits.

${ }^{30}$ These tables only include ordinary business income, not dividends, interest, or capital gains, which we separately account for in the top incomes data. Appendix Table J.3 presents statistics on the number of firms and owners for both S-corporations and partnerships in each industry in Table 3.

${ }^{31}$ Appendix Table J.4 formalizes this observation by presenting a set of correlations at the NAICS 4-digit level, which relate aggregate profits by corporate form to industry-level measures of human capital and nonhuman capital (e.g., physical capital) intensity. Top pass-through profits are most strongly correlated with measures of human capital intensity, whereas C-corporation profits are less correlated with human capital
} 


\subsection{Pass-through Profitability Is Higher for Top Owners}

This section explores how profitability of pass-through firms varies with an owner's position in the income distribution. While other explanations of heterogeneous returns exist, showing that top owners generate excess profitability provides evidence that is consistent with profits reflecting in part the returns to human rather than physical and financial capital. A scalelimiting factor, like the time or personal relationships of a skilled owner-manager, may lead higher demand to manifest itself through higher prices (profits per worker), rather than higher quantities (more workers).

To test whether top-owned firms generate especially high profitability, we begin by binning year-2014 owners in the linked firm-owner-worker data by their fiscal income. We confine attention to the top fiscal income decile, where the vast majority of pass-through income accrues. The bins are one-percentile wide, except in the top $1 \%$ where we consider bins between the 99th percentile and 99.5th percentile, the 99.5th percentile and 99.9th percentile, and the top $0.1 \%$.

We then compute mean profitability - measured as profits per worker - across firms owned by individuals within each personal income bin, with and without controls, as follows. When not using controls, we compute the mean profitability across owner-firm observations within each bin weighting by firm scale (the number of workers). Our main specification controls

for industry (4-digit NAICS), removing profitability variation across owner income bins that is correlated with industry fixed effects (see the figure note).

Figure $4 \mathrm{~A}$ plots the results. Firms owned by top $0.1 \%$ earners enjoy profitability $(\$ 14 \mathrm{~K}$ per worker) that is over twice as large as the profitability ( $\$ 5 \mathrm{~K}$ per worker) of firms owned by individuals in the bottom half of the top decile. The graph displays similar patterns without controls and when controlling additionally for firm size.

Figure 4B demonstrates that high firm profitability is a persistent and systematic characteristic of high earners. It replicates Figure 4A in the subsample of pass-through startups, plotting the profitability-income gradient using owner income ranks from the year before the owner founded the startup. A firm qualifies as a startup in year $t$ if it filed an income tax return in year $t$ and did not file an income tax return of any kind before year $t$. We find all such owner-startup observations in years 2001-2010 and define the owner's income rank using her fiscal income in the year before she founded the startup. Then for each startup year, we produce a profitability-income gradient net of industry fixed effects, using profitability from the startup's fifth year of existence and conditioning on startups that survive for at least five years. We then average those gradients evenly across years and plot the mean gradient and most correlated with physical capital intensity at the industry level. 
in circles in Figure 4B.

Startups founded by top earners go on to be much more profitable in their fifth year than those started by other lower earners. ${ }^{32}$ The panel also shows that we find similar results when including all startups regardless of how long they survive, computing each startup's profitability as total profits in the startup's first five years divided by total annual workers in the startup's first five years. Hence, superior firm profitability is a persistent and systematic characteristic of high earners. ${ }^{33}$

\subsection{Summary of Descriptive Evidence}

Together, this section's descriptive statistics show that a large share of top earners are owners of mid-market firms in skill-intensive industries in the pass-through sector. Pass-through participation is pervasive among top earners who are working age and own undiversified positions in closely held firms. Statistics by industry show that many pass-through firms operate in industries that rely more on human capital than financial capital. That passthrough activity is in many sectors and in firms that are not especially large is at odds with passive capital stories that imply that most profitable activity may be concentrated among a few firms.

\section{The Human Capital Share of Pass-Through Income}

This section presents three event studies: two to quantify the extent to which pass-through income reflects the return to owners' human capital, and a third to test a candidate mechanism. We use the term human capital to refer to all factors embodied in the owner, as opposed to non-human factors such as physical capital, intangible transferable assets (such as patents or brands), or market position. The return to human capital includes the return to labor supply, the owner's network, her retention and recruiting skill, her reputation, and her ability to extract rents. This distinction between labor income - the flow return to human capital - and capital income - the flow return to non-human capital - accords with the definitions in PSZ and elsewhere in the literature. Empirically, the flow return to an owner's human capital includes both wages, which are directly observable, and the share of profits deriving from human capital, which must be estimated.

\footnotetext{
${ }^{32}$ Note that these firms have existed for only five years, so the magnitude of performance advantages may differ relative to the full sample of top-owned firms for firm life-cycle reasons.

${ }^{33}$ Appendix H.1 addresses the question of whether high profitability at top-owned firms reflects payment for higher undiversifiable risk. Based on ex post survival probabilities and Sharpe ratio-like risk adjustments, higher risk does not explain higher profitability among top-owned firms.
} 


\subsection{The Profit Impact of Owner Deaths}

To estimate human capital's share of pass-through profits, an experimental ideal would be to measure the profit impact of exogenously forcing pass-through owners to withdraw their human capital from their firms. We approximate this ideal with a natural experiment in which we measure the profit impact of premature owner deaths. We find that the average premature death of a million-dollar-earning owner causes an $82 \%$ decline in firm profits.

Analysis Sample and Variable Definitions. We construct an owner deaths analysis sample - comprising firms with owner deaths matched to firms without owner deaths - as follows. We obtain owner year of death from Social Security Administration files housed alongside tax records. We refer to a firm-owner-year observation in the linked-firm-owner data as experiencing a year- $t$ owner death when: (a) the owner was aged 64 or younger at the end of year $t$, owned at least $20 \%$ of the firm in $t-1$, and had over $\$ 1$ million in $t-1$ fiscal income; (b) the owner died in year $t \in[2005,2010]$; (c) the firm had no other owners 2001-2014 who died; and (d) the firm had $\$ 100,000$ in sales in $t-1$, the firm had positive sales in all years $[t-4, t-1]$, and the firm had positive employment in some year $[t-4, t-1]{ }^{34}$

We then match each such owner-death firm-owner- $t$ observation to all "counterfactual" firm-owner- $t$ observations that satisfy the following criteria: (a) the firm never had an owner die in the year of or immediately after being an owner; (b) the firm had at least $\$ 100,000$ in sales in $t-1$, the firm had positive sales in all years $[t-4, t-1]$, and the firm had positive employment in some year $[t-4, t-1]$; and (c) the observation matches the owner-death observation along five dimensions. Those five dimensions are: (1) the owners were in the same five-year age bin in year $t,(2)$ the owners were in the same fiscal income bin $\left(99^{\text {th }}\right.$ to $99.5^{\text {th }}$ percentile, $99.5^{\text {th }}$ to $99.9^{\text {th }}$ percentile, or top $0.1 \%$ ) in $t-1$, (3) the firm had the same 3-digit NAICS industry code, (4) the firm had the same sales decile (defined after applying all other sample restrictions) in $t-1$; and (5) the firm had the same organizational form (i.e., S-corporation versus partnership).

The sample restrictions and matching procedure serve the following purposes. Restricting to ages below 65 ensures that we examine owner deaths representative of typical owners (who are working-age) rather than typical dying owners (who skew older). Restricting attention to deaths in years 2005-2010 allows us to construct a balanced panel of firm observations between four years before and four years after the death using our 2001-2014 data. Restricting to firms with substantial pre-period sales and positive employment focuses our analysis on economically active firms. Restricting to owners who own at least $20 \%$ of the firm helps

\footnotetext{
${ }^{34}$ Most dying owners have a firm-owner observation in the year of death. We also include owner deaths that occur one year after the last year the owner appears in our data.
} 
to exclude firms with many owners that typically replace departing owner-managers with new owner-managers such as large law firms. Such replacement would bias toward zero our estimates of the dying owner's human-capital contribution to firm profits, as her human capital supply is simply replaced by a new owner's. ${ }^{35}$ Matching on the various dimensions assists in identifying counterfactual firms that would plausibly exhibit common trends to owner-death firms in the absence of the owner death. The matching procedure is similar to other death-based event studies (Jaravel, Petkova and Bell, 2018; Jäger, 2016) except that it uses all matched counterfactual observations rather than selecting one at random.

After conducting the matches, we construct a balanced panel of firm outcomes for each owner-death firm $j$ and each counterfactual firm $j^{\prime}$ for every year between four years before and four years after the death. If a firm exits (i.e., no longer files a Form 1120S or Form 1065 income tax return), it is coded as having zero profits and zero sales in exited years, except for the reorganization correction defined below. Our owner deaths analysis sample comprises 581,508 matched pair-year observations: nine years of observations on each of 765 firms with a dying million-dollar-earning owner and 64,612 counterfactual firms. We also report results in a broader sample of top $1 \%$ owner deaths $(2,609,973$ observations with 2,436 owner-death firms) and a narrower sample of top $0.1 \%$ owner deaths (194,787 observations with 435 owner-death firms). Appendix Table J.5 provides a waterfall showing how sample restrictions yield our analysis sample size.

Our main outcome is profits per pre-period worker. This quantity in a year $s$ equals firm profits in $s$ divided by the firm's mean annual workers across years $[t-4, t-1]$ where $t$ denotes the owner death year. Scaling profits by the average annual number of pre-period workers permits comparison across firms of different pre-death size. Because the denominator is defined using only pre-death observations, post-death changes in the number of workers do not directly affect the outcome. For example, a firm with constant profits that happens to replace employees with equally compensated independent contractors would exhibit zero change in profits per pre-period worker. We also analyze firm survival, equal in a year $s$ to an indicator for whether the firm has positive sales in $s$.

Forty-one percent of the owner-death firms and $17 \%$ of counterfactual firms exit the sample between $t$ and $t+4$. Some of these exits do not represent firm shutdowns and instead represent firm reorganizations under a different employer identification number either through bankruptcy or sale. We do not directly observe firm reorganizations. However, we can infer reorganizations by whether most of the exiting firm's workers subsequently appear

\footnotetext{
${ }^{35}$ This restriction excludes few firms, and the main coefficient estimate is slightly larger in absolute magnitude when including them. Firms with a very large number of owners are excluded by the restriction that only one owner died 2001-2014.
} 
as coworkers at another firm. Specifically, for every firm that had zero sales in year $t+4$ and denoting its first year of zero sales (i.e., its first fully exited year) by $r$, we identify the largest single employer other than the exiting firm across years $r$ and $r+1$ of the firm's $r-1$ workers excluding the dying owner. ${ }^{36}$ We find that $22 \%$ of exiting owner-death firms and $28 \%$ of exiting counterfactual firms with at least two $r-1$ workers were reorganizations: the largest single employer following the owner death employed over half of the exiting firm's $r-1$ workers. We account for these reorganizations by simply replacing the firm's profit in years $[r, t+4]$ with the firm's profit in year $r-1 .^{37}$

Estimates. We use our owner deaths analysis sample of matched owner-death and counterfactual firms to estimate difference-in-differences impacts of owner deaths, as follows. Let $j$ denote an owner-death firm and $j^{\prime}$ denote one of its matched counterfactual firms. For each matched pair-year observation, we compute the difference in the outcome of interest between the owner-death firm and the counterfactual firm in the given year, i.e., $\Delta Y_{j j^{\prime} s} \equiv Y_{j s}-Y_{j^{\prime} s}$. We then regress that difference on event-time indicators in an event study specification:

$$
\Delta Y_{j j^{\prime} s}=\sum_{k \in\{-4,-3,-2,0,1,2,3,4\}} \beta_{k} D_{j s}^{k}+\varepsilon_{j s}
$$

where $D_{j s}^{k}$ is an indicator for owner-death firm $j$ having experienced an owner death $k$ years in the past. The coefficients of interest $\beta_{k}$ provide the time path of mean owner-death firm outcomes relative to the year before the owner death, which is normalized to zero. Note that because there are no controls, the coefficients $\beta_{k}$ are raw differences-in-differences of the outcome means between owner-death firms and counterfactual firms between year $t-1$ and other years. We ensure that each owner-death firm carries equal weight in the regression by weighting each $j j^{\prime} s$ observation by one over the number of counterfactual $\left(j^{\prime}\right)$ firms matched to the owner-death firm $(j)$. We cluster standard errors by owner-death firm $j$.

Figure 5A plots our main owner-death result: point estimates and 95\% confidence intervals from equation (1) for the outcome of profits per pre-period worker. The flat pre-period

\footnotetext{
${ }^{36}$ We measure employer as the employer identification number (EIN) listed on the W-2. Because we use W-2 EIN to identify both the owner-death firm's $r-1$ workers and the firms subsequently employing those workers, employer is consistently measured before and after the owner death. We search for the largest single employer across all of a worker's $r$ and $r+1$ employers, not just the highest-paying one.

${ }^{37}$ This correction is analogous to how Chetty and Saez (2005) correct for firms that de-list from stock exchanges, thereby exiting Chetty and Saez's analysis sample. Moreover, we neither observe nor infer division spinoffs, which would reduce measured profits at the surviving owner-death firm despite no real reduction in economic activity. However, we believe that spinoffs are likely rare for the medium-sized firms we study. In order to explain the very large effects we find below, very large shares of most owner-death firms would have to have been spun off. Online Appendix H.2 tests robustness of punchline calculations to potential bias.
} 
trend corroborates the common trends assumption underlying our difference-in-differences analysis - that in the absence of the owner death, profits per pre-period worker among ownerdeath firms and among counterfactual firms would have trended similarly. The graph shows that profits per pre-period worker decline immediately and persistently at owner-death firms relative to counterfactual firms upon owner death. ${ }^{38}$ The immediate decline in profits can derive from a number of mechanisms. The firm could contract (e.g., by closing one of many store fronts) in response to worse managerial inputs. Owner charisma or connections may have kept key employees at the firm until her death. Or a firm could replace its dead ownermanager (compensated in profits) with a hired non-owner manager (compensated in wages), yielding a decline in measured profits. In each of these cases, the withdrawal of the owner's human capital caused profits to decline.

The graph's rightmost data point, also reported in Table 4A Column 1 , is our main estimate: the average death of a top-earning owner caused a $\$ 20,591$ decline in profits per pre-period worker four years after the owner death. This estimated impact has a t-statistic of 3.5. The bottom rows of the column transform the estimated dollar impact into a percentage impact as follows. The mean profits per pre-period worker at counterfactual firms in $t+4$ was $\$ 38,401$. The average dying owner had an ownership share of $65.7 \%$ and thus, on average, may have withdrawn only $65.7 \%$ of the firms' owners' human capital contributions. Dividing - $\$ 20,591$ by $\$ 38,401$ and by $65.7 \%$ yields an estimated impact of an effective $100 \%$ owner death of $-81.6 \%$, our preferred percentage impact.

Columns 2-3 separate Column 1's main effect into extensive and intensive margins. Column 2 finds that the mean death of a top-earning owner caused her firm to be 19.8 percentage points less likely to have survived four years after the owner death, relative to counterfactual firms. This extensive-margin effect size has a t-statistic of 11.6. Column 3 restricts the sample to firms that survive through $t+4$, finding an intensive margin effect of $-\$ 13,252$ that is marginally significant with a t-statistic of $1.9 .^{39}$ Comparison of bottom-row values of Columns 1-3 suggests that most of the Column 1 impact is along the intensive margin.

Columns 4-7 report heterogeneity and placebo results that corroborate the interpretation of owner death impacts as reflecting the withdrawal of the owner's human capital services. One might expect majority owners to be more likely to actively manage their firms than minority owners, implying that a majority owner death causes a larger decline in firm profits

\footnotetext{
${ }^{38}$ Though the graph shows a flat time series of dollar estimates, percentage estimates scaled by the outcome of mean of counterfactual firms exhibit a slight downward trend as profits at counterfactual firms secularly decline over time.

${ }^{39}$ The analogous t-statistic among top $1 \%$ owner deaths is 4.6 , as the sample is substantially larger (Online Appendix Table J.7). While conditioning on survival entails conditioning on an endogenous outcome, we nevertheless report it for interpretation in combination with Columns 1-2.
} 
than a minority owner death. Columns 4-5 test this prediction by repeating Column 1 on the subset of owner-death firms with dying minority owners (those with less than or exactly $50 \%$ ownership) and firms with dying majority owners (all others), respectively. Both columns reveal large and statistically significant profit impacts, but the dying-majority-owner impact is nearly twice as large as the dying-minority-owner impact. This pattern is consistent with profit impacts of owner deaths stemming from the withdrawal of human capital services.

Recall that our owner deaths analysis sample restricts to owners below age 65 . Nonelderly owners are more likely to be active managers than elderly owners. We therefore construct a sample of elderly owner deaths - exactly analogous to the main owner deaths analysis sample, except restricting to owners who died at age 75 or greater and to counterfactual firms with similarly aged owners. Column 6 repeats Column 1 in the elderly owner deaths sample. We find an insignificant and near-zero impact of an elderly owner death on firm profits.

Earlier work has assumed that $0 \%$ of S-corporation profits is labor income (Karabarbounis and Neiman 2014, PSZ) but that 70\% of partnership profits is labor income (PSZ). While the partnership assumption is close to our main estimate, the S-corporation assumption is not. Column 7 repeats Column 1 while restricting the sample to S-corporations. The resulting estimate is similar to the main estimate, indicating that the main estimate is not simply driven by partnerships. ${ }^{40}$

Finally, Columns 8-9 repeat Column 1 in our broader and lower-mean-income top 1\% sample and our narrower and higher-mean-income top $0.1 \%$ sample. ${ }^{41}$ Effects are ordered across our three top groups in both dollar and percentage terms. In particular, we find a $-72.9 \%$ impact of top $1 \%$ owner deaths and a noisier $-92.3 \%$ impact of top $0.1 \%$ owner deaths, compared to the $-81.6 \%$ impact of a million-dollar-earner death. ${ }^{42}$ See Online Appendix Table J.7 for full top $1 \%$ and top $0.1 \%$ owner-death results.

\subsection{The Profit Impact of Owner Retirements}

A natural concern is that, because an owner death may be unanticipated, the prior section's results may primarily reflect a chaotic disruption rather than the withdrawal of the owner's human capital. We therefore complement our owner-deaths analysis by estimating the impact of inferred orderly transitions of owners out of employment at their owned firms ("retirement").

\footnotetext{
${ }^{40}$ Our sample is dominated by dying S-corporation owners, due in large part to the $20 \%$ ownership share threshold and to requiring the firm to have had positive pre-period workers.

${ }^{41}$ The million-dollar-earner sample includes everyone in the top $0.1 \%$ sample; the top $1 \%$ sample includes everyone in the million-dollar-earner sample.

${ }^{42}$ An earlier draft reported a smaller impact for top $1 \%$ owner deaths (see Online Appendix H.4 for details).
} 
Specifically, we follow the owner-deaths sample frame and matching procedure detailed in Section 3.1, with four amendments. First, rather than defining an owner-death event, we define an owner-retirement event in year $t$ as the firm transitioning from consecutive years $[t-4, t-1]$ with at least one owner receiving $\mathrm{W}-2$ wages (perhaps different owners in different years) to years $[t, t+1]$ with no owner receiving $\mathrm{W}-2$ wages while still having positive sales. Second, we match owner-retirement firms to counterfactual firms at which at least one owner received $\mathrm{W}-2$ wages in consecutive years $[t-4, t+1]$. Third, we allow owners to be any age because elderly owners working at their firms may nevertheless be representative of typical owners. Fourth, we require owner-retirement and counterfactual firms to have positive sales $[t-4, t+1]$ rather than merely $[t-4, t-1]$ because exited firms cannot be classified into ownerretirement or counterfactual categories. We make no restrictions at all on owner-retirement or counterfactual firms in years $[t+2, t+4]$. The owner-retirements sample is substantially larger than the owner-deaths sample, with 5,312 owner-retirement firms compared to 765 owner-deaths firms. Appendix Table J.6 provides a waterfall showing how sample restrictions yield our analysis sample size.

Our owner-retirements research design has strengths and weaknesses relative to our owner-deaths research design. Its primary strength is that it may identify instances where an actively participating owner is replaced by a hired non-owner manager, without the disruption of an unanticipated death. Replacement of an actively participating owner by a non-owner-manager rather than by another owner is helpful for our analysis. This replacement can induce a change in compensation: profits to the owner-manager replaced by the salary of a non-owner-manager. In contrast, replacing an active owner with another equally productive active owner could yield zero change in profits despite profits entirely reflecting returns to owner human capital. On the other hand, death is measured with almost no error from vital records, whereas retirement is only inferred. In fact, we find suggestive evidence that many inferred retirements are not actual retirements: $13 \%$ of retirement firms issued a $\mathrm{W}-2$ in $t+4$ to at least one of its owners. Thus, our owner-retirement estimates may understate the true effect of withdrawing owner human capital.

We estimate our event study specification equation (1) in our owner retirements sample and report the results in Figure 5B and Table 4B. Figure 5B's flat pre-retirement trend corroborates our identifying assumption that, in the absence of retirement, owner-retirement firms and counterfactual firms would exhibit common trends in profits per pre-period worker. Profits per pre-period worker decline immediately and persistently in the year of retirement.

The rightmost estimate in Figure 5B is reported in Column 1 of Table 4B: an estimated causal impact of $-\$ 37,210$ with a t-statistic of 9.3 . The bottom row follows the same calculations used in Panel A to arrive at our preferred owner-retirement percentage impact 
of $-82.5 \%$. This preferred estimate is nearly identical to our owner-deaths estimate of -81.6\%. Columns 8-9 present analogous estimates for top-1\%-owner retirements and top0.1\%-owner retirements: $-59.6 \%$ and $-71.7 \%$ respectively (see Online Appendix Table J.8 for full results).

Discussion. Our analysis below requires an estimate of the share of top pass-through income that is a return to owner human capital. Million-dollar earners are the middle of the three top groups on which we focus; both the owner-deaths and owner-retirements specifications for this group suggest an estimate of $82 \%$. The estimated owner-retirement impacts are monotonic across top income groups in dollar terms but not in percentage terms. Motivated by the possibility of specification noise and effectively weighting high-earners the most, the average of the six percentage impacts (top 1\%, million-dollar-earners, and top $0.1 \%$ across both owner deaths and retirements) is $76.8 \%$.

To further explore the robustness of these estimates, Appendix Table J.9 compares the equal-weighted estimates in Table 4 for the top $1 \%$ to alternative specifications that weigh observations using average pre-event profits. Recall that top-owned pass-throughs are much smaller than public companies: $72 \%$ of top-1\% pass-through profits accrue to firms with less than $\$ 50 \mathrm{M}$ in profits (see Figure 3 and Appendix Figures I.3 and I.4 for distributions by firm size). Superstar firms such as Amazon are not prominent, even on a dollar-weighted basis, within the pass-through sector. Thus, equal-weighted estimates within the pass-through sector are a priori likely to be close to dollar-weighted estimates.

To explore this point, we consider multiple dollar-weighting schemes and subsample analyses to evaluate how sensitive the overall estimates are to how we treat the largest firms. First, weighting by the log of pre-period profits increases the estimated percentage impact in both the owner-death and owner-retirement samples with little loss of precision. Second, we implement a bounding exercise in which we estimate dollar-weighted treatment effects for all but the largest firms and bound the overall effect by assuming the full range of treatment effects from $0 \%$ to $100 \%$ for the largest firms. For owner deaths, we find a dollar-weighted treatment effect for firms with less than $\$ 50 \mathrm{M}$ in pre-event profits of $87.1 \%$. Such firms generate $72 \%$ of total top $1 \%$ pass-through profits, so we bound the overall effect from $62.4 \%$ $(=0.72 \times 87 \%+(1-0.72) \times 0 \%)$ to $90.8 \%(=0.72 \times 87 \%+(1-0.72) \times 100 \%)$. Owner retirements deliver larger estimates.

Overall, dollar-weighted approaches deliver similar if not larger estimates relative to the equal-weighted analysis, although the standard errors do increase with dollar-weighting. For the next section's analysis, we use $75 \%$ as a round number robustly supported by all weighting approaches. We also report analyses using smaller shares in both the person-level 
and dollar-level calculations. ${ }^{43}$

The findings in this and the previous section contribute to a literature on the effect of managers and CEOs on firm performance using research designs based on retirements, family succession, and CEO deaths. Johnson, Magee, Nagarajan and Newman (1985), PérezGonzález (2006), and Bennedsen, Nielsen, Pérez-González and Wolfenzon (2007) find that, when replacing an outgoing $\mathrm{CEO}$, choosing an external CEO increases firm value and performance relative to choosing a within-family CEO. In Danish administrative data, Bennedsen, Perez-Gonzalez and Wolfenzon (2010) and Bennedsen, Perez-Gonzalez and Wolfenzon (2012) use CEO deaths and hospitalizations, respectively, to show that these events cause significant declines in profitability, with larger effects for CEOs who are younger and more likely to be actively involved in the firm's operations. ${ }^{44}$

The estimates from our owner death design are considerably larger than estimates from these studies, which find average effects of professional CEOs between 10 and 25 percent in terms of operating profitability. Two factors can naturally explain the discrepancy. First, previous work has tended to estimate the effect of one CEO being replaced by another CEO, thereby identifying only the difference in human capital returns between two managers. In contrast, our estimates aim to measure the full human capital return of a manager appearing in profits, as a firm replaces an owner-manager (whose human capital return may for tax reasons appear in profits) with a hired manager (who would be compensated in wages). Second, previous work has often estimated effects among especially large or publicly traded companies that may be more capital intensive than the typical firm in the economy. Capital intensive firms like an oil extraction firm may depend less than other firms on managerial talent. Becker and Hvide (2017) find large effects of entrepreneur deaths on quite small firms in Norway. Relative to their work, our study broadens the scope of analysis to much larger firms with high-income owners in a different institutional context that directly informs the character of top U.S. incomes. ${ }^{45}$

\footnotetext{
${ }^{43}$ We use fiscal income in defining the owners' groups for Table 4 . The top $1 \%$ estimates are smaller than the estimates based on higher-earners, so it is likely that the top 1\% estimates defined using imputed national income - whose thresholds are higher than fiscal income thresholds - would be larger.

${ }^{44}$ Consistent with our findings, Jäger (2016) uses German data to show that manager deaths cause a decline of average yearly wages among incumbent workers of approximately $1 \%$. However, his paper does not estimate effects on firm performance.

${ }^{45}$ Among our million-dollar-owner-death firms, the mean number of employees is 172 and the median is 41. Among Becker and Hvide's owner-death firms, the median number of employees is 4. Becker and Hvide find statistically significant effects of owner deaths on firms in the first four quintiles of firm size but not on firms in the largest quintile (those with more than 8 employees).
} 


\subsection{The Profit and Wages Impacts of Corporate-Form Switching}

We have found that most pass-through profits represent the returns to human capital. We now test a tax-incentive mechanism for these returns being reported on business tax returns (and thereby recorded in National Accounts) as pass-through profits, rather than as wages paid to the owner. As discussed in Section 1.1, private firms have considerable leeway in how they pay owners and face differing tax incentives to use that leeway: C-corporations face tax incentives to pay owners in wages, while pass-throughs face tax incentives to pay owners in profits. We investigate the tax-incentive mechanism by testing for a sudden divergence in profit and wage trends after firms transition from C-corporation form to pass-through form.

We collect data on the population of businesses that switch from C-corporation to Scorporation form between 2001 and 2014. ${ }^{46}$ On average, approximately sixty-seven thousand C-corporations switch each year, corresponding to between 3 and 5 percent of all C-corporations. We study total wage payments or profits as a fraction of contemporaneous firm sales in an event study framework:

$$
Y_{i t}=\sum_{k \in\{-5+,-4,-3,-2,0,1,2,3,4,5+\}} \gamma_{k} D^{k}+\alpha_{i}+\delta_{t}+\varepsilon_{i t},
$$

where $\gamma_{k}$ is the coefficient vector of interest on event time indicators, $\alpha_{i}$ are firm fixed effects, and $\delta_{t}$ are calendar-year fixed effects. ${ }^{47}$ Wage payments equals Salaries and wages plus Compensation of officers as listed on the business income tax return. ${ }^{48}$ The analysis sample includes 157,272 firms that switched from C-corporation form to S-corporation form between 2001 and 2010. The sample includes all firms that existed for at least 4 years prior to and 4 years following the switch and generated at least $\$ 100 \mathrm{~K}$ in sales in the year prior to the switch.

Figure $6 \mathrm{~A}$ plots the impacts on profits and wage payments for all firms in the switchers analysis sample. Despite a pre-period trend in profits, the graph shows a sharp divergence between profits and wages in the year of the switch. Wage payments fall sharply in the switching year by $2.29 \%$ on average relative to sales, and this decline in wage payments is offset by an average profit margin increase of $1.70 \%$. In words, nearly two percent of sales are suddenly paid as profits instead of wages upon switching to S-corporate firm. This pattern is

\footnotetext{
${ }^{46}$ Over this time period, the vast majority of transitions were from C- to S-corporation form, rather than from S- to C- or from C- to partnership. There are few in the former case because of tax preference for the S-corporation form that began in 1986. There are few in the latter case because of rules requiring the firm to un-incorporate in the event of these transitions.

${ }^{47}$ We cannot directly study changes in owners' wage payments because C-corporations are not linked to owners, without assuming no changes in ownership before the switch.

${ }^{48}$ This sum should typically equal total W-2 payments, except for manufacturing firms which deduct production-worker wages on a separate form unavailable to us.
} 
consistent with the tax-incentive mechanism for pass-through owners' human capital returns being paid as profits.

Figure 6 plots two heterogeneity analyses that further support the tax-incentive mechanism. S-corporation profits must be distributed pro rata to ownership share. A firm with one active owner-manager supplying human capital and a passive owner supplying none would therefore be relatively unlikely to characterize human capital returns as profits. Instead, the active owner-manager would likely insist on being paid in salary or bonus - sacrificing taxes in order to not share her human capital returns with a passive owner. Non-majority-owned firms are relatively likely to have at least one passive owner, so we would expect such firms to exhibit a smaller change in profits and wage payments after a C-to-S switch. Figure 6A shows that expectation is indeed in the case empirically. When limiting the sample to the 14,600 firms with no owner in the year of the switch having at least a 50\% ownership share, the change in profits and wage payments is markedly less pronounced than in the full sample.

Human capital is a primary factor of production in high-skilled service-sector firms such as medical practices and consultancies. Owners of such firms may be especially likely to also serve as a manager rather than hiring a non-owner manager, and the labor share of value added tends to be higher at such firms. High-skilled service-sector firms may therefore exhibit especially large changes in profits and wage payments after a C-to-S switch. Figure $6 \mathrm{~B}$ shows that that is indeed in the case. When limiting the sample to the 53,220 firms with 2-digit NAICS $\in\{51,52,54,56,61,62\}$ in the year of the switch, the change in profits and wage payments is markedly more pronounced than in the full sample. We conclude that the data support the tax-incentive explanation for human capital returns being recharacterized as pass-through profits.

\section{Characterizing Top Earners and Incomes}

\subsection{Most Top Earners Are Human-Capital Rich}

This subsection uses our estimates to characterize top earners as human-capital rich or financial-capital rich. The question is whether a very high earner you might meet on the street likely earns most of her income from her human capital or her financial capital. The answer plays a key role in debates about taxation. Kuziemko, Norton, Saez and Stantcheva (2015) find that survey respondents assess tax policy in part based on how income is earned. Moreover, traditional models of optimal taxation provide rationales for higher tax rates on labor income than on capital income (Atkinson and Stiglitz, 1976; Chamley, 1986; Judd, 1985). To the extent that "capital" income is characterized as labor income, higher capital 
tax rates may be optimal (Piketty and Saez, 2013).

We classify a top earner as human-capital rich if the majority of her income derives from her human capital, which we refer to as labor income as in PSZ and elsewhere in the literature. We measure labor income as the sum of wage income (as defined in Section 1.2) and $75 \%$ of pass-through income (based on our owner-death and owner-retirement event studies). We use our two measures of personal income - fiscal income and imputed national income - and report results for three top income groups - the top 1\%, million-dollar earners, and the top $0.1 \%$. Recall that the unit of observation in fiscal income is the tax unit and in imputed national income is the individual. Because imputed national income uses imputed C-corporate retained earnings and other passive capital income, labor income is lower when using the imputed national income measure.

Figure 7 displays the results for 2014. Figure 7A shows how the results in Figure 1A change when adding the human capital share of pass-through income within the top decile, and Figure 7B focuses on our three top income groups. As a benchmark, we first plot the share of top earners who earn a majority of their income in wages. If $0 \%$ of pass-through income is labor income, the wage-earner share would equal the human-capital-rich share. Within the top decile, the share of people earning most of their income from wages falls dramatically at the top. Across five of the six top income groups, a minority of top-earners are wage earners. For example among million-dollar earners, $46.8 \%$ are wage earners in the fiscal income definition and only $35.4 \%$ are wage earners in the imputed national income definition. Thus, when ignoring pass-through income, a minority of top earners appear to be human-capital rich.

That conclusion reverses when classifying $75 \%$ of pass-through income as labor income. The share earning most of their income from human capital falls much less within the top decile. The figure's "human-capital rich" series reveal that most top earners are humancapital rich, not financial-capital rich. For example among million-dollar earners, 88.8\% are human-capital rich in the fiscal income definition and $67.4 \%$ are human-capital rich in the imputed national income definition. Even among the top $0.1 \%$ in the imputed national income series, $56.2 \%$ are human-capital rich, relative to only $23.3 \%$ being primarily wage earners. We conclude that the human capital component of pass-through income transforms one's view of whether the typical top earner is human-capital rich.

Online Appendix H.2 provides two robustness analyses. The first uses the minimum estimate of the labor share of pass-through income by income group in Table 4, rather than the mean of $75 \%$. The second classifies all private C-corporation wages as capital income. In each of twelve permutations, a majority of top earners are human-capital rich.

Finally, we may in fact understate the human-capital-rich share of top owners because 
pass-through income is not the only form of "capital" income that includes recharacterized wages. In particular, there are prominent tax-advantaged ways to use C-corporation retained earnings to compensate entrepreneurs, hired managers, private equity and angel investors for their human capital services. ${ }^{49}$ Estimating the human capital content of C-corporation income is a priority for future work.

\subsection{Most Top Earners in the 1980-1982 Cohort are Self-Made}

A potential concern with the preceding analysis is that some people with high wages may in fact be providing little human capital services, even when not earning wages from a private C-corporation. In particular, drawing a salary from a family pass-through can be an effective way for a rich family to avoid estate taxes. In such cases, an individual could be erroneously labeled as human-capital rich.

We therefore analyze the concept of being self-made, as opposed to being a financial heir. Analogous to Piketty, Postel-Vinay and Rosenthal (2014), we define an individual as self-made if she earns most of her income from her human capital or from savings out of her previous human capital returns, rather than from inherited financial capital. U.S. tax data lack detailed information on inheritances. However, we can link young top earners to their parents. In the parent-linked sample, we can therefore compute a likely conservative estimate of the self-made share of top earners under the assumption that top earners with sufficiently-low-earning parents almost surely do not have high incomes through financial inheritance.

Specifically, we attempt to link all of the individuals born 1980-1982 in our top incomes data to parent-income percentiles, using parent-child links and parent income percentiles provided by Chetty, Friedman, Saez, Turner and Yagan (2019). The year 1980 is the first birth cohort for which parent income can be measured. We match $83 \%$ of top $1 \%$ individuals born in 1980-1982 to their parents; parent income is unavailable for individuals who immigrated to the United States after their teenage years. Parent income is defined as mean adjusted gross income of the child's parents when the child is aged 15-19. Parent-income percentiles are defined within birth cohorts, with the top $1 \%$ ranging between $\$ 511 \mathrm{~K}$ and $\$ 552 \mathrm{~K}$ in 2014 dollars. Bottom $99 \%$ parents are therefore unlikely to have assets above

\footnotetext{
${ }^{49}$ First, private equity managers often receive compensation for their management services via high retained earnings of portfolio companies. Second, entrepreneurs like Bill Gates are often compensated in "sweat equity"(Bhandari and McGrattan, 2018), thereby earning a much larger share of C-corporation income than non-manager investors who contributed identical financial inputs. Third, hired executives at mid-stage startups can be compensated with special underpriced shares such that the executive receives a large capital gain if not fired. Fourth, startups permit angel investors and other venture capitalists to invest at discounts as compensation for the investors' human capital services, such as operating advice and business connections.
} 
the 2014 estate tax exemption of $\$ 5.3$ million and unlikely to make large enough financial bequests to place a child into a top income group. We therefore classify an individual as self-made if her parents were not in the top $1 \%$. This is a conservative classification, as many children of the top $1 \%$ do not work for their parents' firms and do not receive especially large financial inheritances. ${ }^{50}$

Figure 7B plots the results. A slightly larger share of the parent-linked sample is classified as human-capital rich than in the overall sample, but the differences are small. The figure shows that, across income definitions and top income groups, more than three out of four of top earners in the parent-linked sample did not have top $1 \%$ parents. For example among million-dollar earners, $85.1 \%$ in the fiscal income series and $75.3 \%$ in the imputed national income series are self-made. The remaining bars plot similar statistics for human-capital rich (i.e., those with majority income from labor) and entrepreneurs (i.e., those with majority income from pass-throughs). In all cases, at least $74 \%$ are self-made. Thus, children of the top $1 \%$ are very disproportionately represented among young million-dollar-earners but do not constitute a majority. Recall that these self-made statistics are likely lower bounds, as many adult children of the top $1 \%$ are in reality also not dependent on financial inheritance. While we can measure these outcomes only for the 1980-1982 cohorts, the results support the conclusion that our human-capital rich statistics are robust to excluding any financial inheritances recharacterized as labor income.

Note that Chetty, Hendren, Kline and Saez (2014) (henceforth CHKS) published a 100by-100 appendix transition matrix that suggests an even higher self-made share of $90.4 \%$. Yet because they measure child income within the 1980 birth cohort rather than nationally, many of their top $1 \%$ children were not currently in the overall top $1 \%$ and in particular were not million-dollar earners or in the top $0.1 \%$. Our self-made statistics reach further into the tail of the income distribution and are computed in both fiscal income (as in CHKS) and in imputed national income. ${ }^{51}$

\subsection{Top Labor Income and Entrepreneurial Income Are Large}

This subsection uses our labor-versus-capital classification of pass-through income to characterize the labor share and the entrepreneurial share of top incomes. One reason the top

\footnotetext{
${ }^{50}$ Averaging parent incomes over five years smooths out fluctuations in parental income, for example, due to temporary business losses. While it is possible that children receive large inheritances from rich grandparents, it is unlikely that the middle generation (i.e., the parents) would have relatively low income.

${ }^{51}$ CHKS find that children's income ranks stabilize by their early 30s, suggesting that most of their top $1 \%$ children will eventually lie in the overall top $1 \%$ as their incomes grow over the lifecycle. CHKS measure parent and child incomes using fiscal income. They do not publish their top 1\% child income threshold, but their top $1 \%$ child income mean $(\$ 423 \mathrm{~K}$ in 2014 dollars) is nearly the same as our top $1 \%$ fiscal income threshold $(\$ 390 \mathrm{~K})$, which implies that their top group encompasses substantially lower earners than ours.
} 
$1 \%$ are of interest is that their earnings constitute a disproportionate share of the economy and tax base. Therefore, it is useful to conduct a dollar-level analysis of top earners that complements our person-level analysis.

We divide top pass-through income into labor and capital portions and then add other sources of labor and capital income to account for total top income. As above, we allocate $75 \%$ of top pass-through income to labor and the rest to capital. ${ }^{52}$ We also use our linked firmowner-worker files to determine how much W-2 wage income accrues to pass-through business owners, which enables us to quantify total top entrepreneurial income. These contributions enable a more comprehensive analysis of the nature of top earners' income-how much is labor income, how much is entrepreneurial income, and how these amounts compare to other income components - than has been possible. We find that top labor income and top entrepreneurial income are substantial and larger than previously documented.

Figure 8A shows how the results for the top decile from Figure 1B change when combining wage income and the human capital component of pass-through income. Figure 8B shows results for our top income groups. We present two findings. First, and despite the fact that capital income accrues disproportionately to top earners, we find that a large share of top income is labor income. In particular, $76 \%$ of top $1 \%$ fiscal income and $53 \%$ of top $1 \%$ imputed national income is classified as labor income. Hence, our classification of three-quarters of pass-through income as labor income reverses the earlier finding in PSZ that a minority $(45 \%)$ of top $1 \%$ imputed national income is labor income. Even among million-dollar earners, $70 \%$ of fiscal income and $47 \%$ of imputed national income is labor income. In the top $0.1 \%$, labor income shares fall to the still large numbers of $67 \%$ and $42 \%$, respectively. ${ }^{53}$

Second, top entrepreneurial income is large. We define entrepreneurial income as the sum of two components: (a) pass-through income, and (b) W-2 wage payments to pass-through owners. Figure 1 showed that $32-39 \%$ of top $1 \%$ and top $0.1 \%$ fiscal income is pass-through income. Adding owner wage payments, which has not been previously possible, increases top entrepreneurial income to 39-45\%. Note that some portion of C-corporation income also accrues to founders, so a broader definition of entrepreneurial income would yield larger estimates. ${ }^{54}$

\footnotetext{
${ }^{52}$ See Online Appendix Figure I.8 for results using alternative labor shares. See also Online Appendix Figure I.10 for alternative results when reclassifying all wages from private C-corporations as capital.

${ }^{53}$ To demonstrate robustness of these results, we consider two conservative scenarios. Online Appendix Figure I.8 shows that the top 1\% labor share in imputed national income is $48 \%$ when classifying only $59.6 \%$ (56\% after tax imputations) of pass-through income as labor income. Online Appendix Figure I.10 shows that the top $1 \%$ labor share in imputed national income is $47 \%$ when very conservatively reclassifying all private $\mathrm{C}$-corporation wages as profits.

${ }^{54} \mathrm{~A}$ large share of C-corporation income is earned by publicly traded companies and does not accrue to founders in the year it is earned. For example, Jeff Bezos became 2018's richest person in the world largely
} 
Top entrepreneurial income is large relative to all other income components. In every top income group and income definition, entrepreneurial income rivals or exceeds both non-owner wage income and non-pass-through capital income. For example among milliondollar earners, $44 \%$ of fiscal income and $36 \%$ of imputed national income is pass-through entrepreneurial income. In contrast, $37 \%$ of fiscal income and $22 \%$ of imputed national income is non-owner wage income, and $19 \%$ of fiscal income and $43 \%$ of imputed national income is non-pass-through capital income. Notably, entrepreneurial income far exceeds Ccorporation (and therefore public equity) income, which amounts to $8 \%$ of fiscal income and $19 \%$ of imputed national income. Hence, entrepreneurial income constitutes a large portion of U.S. top incomes.

\section{The Growth of Top Entrepreneurial Income}

This section puts the cross-sectional results on top business income in the context of how top income inequality has evolved over the past five decades. We find that top pass-through income has grown dramatically over time, even after adjusting for tax-induced organizational form switching. We then use our linked firm-owner-worker data from 2001-2014 to decompose this growth into three components-labor productivity, redistribution from workers to owners, and sectoral scale. We find important roles for the growth in labor productivity as well as redistribution from workers to owners.

\subsection{The Sources of Top Income Growth}

As in Section 2.1, we decompose top incomes into three sources: wage income, business income, and other capital income. Figure 9A plots the time series of these sources using top fiscal income and imputed national income. Figure 9B plots the time series of the two components of business income: pass-through income and C-corporation income. Figure 9C

plots the time series of the top $1 \%$ labor share, defined either with or without the human capital component of pass-through income.

Three facts emerge. First, the second half of the twentieth century saw a spectacular rise in wage income for top earners. However, since the late 1990s, rising top wage income ceded to rising top non-wage income.

by founding Amazon. He owned 48\% of Amazon prior to its 1997 IPO but sold most of that stake by 2018, so the vast majority of Amazon's 2018 profits accrued to people other than Bezos. Hence, even if C-corporations could be linked to owners, the national income concept has limitations in classifying entrepreneurial income. The Haig-Simons income concept, which includes price-driven capital gains omitted from the national income concept, could prove fruitful in future work. 
Second, the vast majority of rising top non-wage income came in the form of business income. ${ }^{55}$ In both fiscal and imputed national income, the path of top wage income mirrors the path of top business income, suggesting that some of the observed slowdown in top wage growth manifested in faster business income growth. Indeed, adding $75 \%$ of pass-through income to wage income in defining the top $1 \%$ labor share substantially attenuates the decline in top labor income since the 1990s. Specifically, the top 1\% labor share in fiscal income exceeds $75 \%$ without much of a trend since the late 1980s. In imputed national income, the top $1 \%$ labor share is lower (53\%), having surged above $60 \%$ in the late 1990 s and returned to its post-1985 average in recent years.

Third, within business income, most of the growth took the form of pass-through income, rather than C-corporation income. The enduring impact of the Tax Reform Act of 1986 on the distribution of business income is clearly visible in these series (Gordon and MacKieMason, 1994; Slemrod, 1996; Mackie-Mason and Gordon, 1997; Gordon and Slemrod, 2000; Clarke and Kopczuk, 2017). As the reform raised the burden on traditional C-corporations and lowered top personal income rates, pass-through income jumped and has been steadily rising ever since, as new and growing businesses are more likely to choose pass-through form. Pass-through income growth features centrally in both the fiscal income and imputed national income series, which also includes imputed C-corporation retained earnings.

In Online Appendix F, we quantitatively evaluate the relative contributions to top income growth and business income growth over 1990-2014 and 2000-2014 of various business income sources under alternative approaches for imputing retained earnings. We estimate that passthrough accounts for 60-73\% of the business income growth since 1990 and 38-56\% of the business income growth since 2000. ${ }^{56}$ Retained earnings account for more than two-thirds of C-corporation income growth, which underscores the importance of including retained earnings when studying top income growth. Understanding the rise of retained earnings, how it contributes to the aggregate capital share, and the rise of superstar firms is an important topic for ongoing and future research.

Pass-through Growth Is Not Just a Reporting Phenomenon. Rising top passthrough income partly reflects a type of relabeling of business income, as preexisting busi-

\footnotetext{
${ }^{55}$ In both fiscal income and imputed national income, the components of non-wage income not included in business income are much less consequential. The fiscal income shows essentially no growth in this category, whereas the imputed national income series shows modest growth, though some disagreement remains about the size of this increase. See Auten and Splinter (2018), and Bricker, Henriques, Krimmel and Sabelhaus (2016).

${ }^{56}$ The year 2000 appears to be a local minimum for C-corporation income, likely driven by business cycle fluctuations. The more robust fact is the reversal of C-corporation income and pass-through income in the overall contribution to top income inequality over the past 50 years.
} 
nesses reorganized from C-corporation to pass-through form and entrants increasingly chose pass-through form following TRA86. Focusing on the period 2001-2014 during which our linked firm-owner data are available, the pass-through share of total business sales - which rose from approximately $10 \%$ in the mid-1980s to $20 \%$ in 1990 to $35 \%$ in recent yearsindicates that some share of rising top pass-through income is an artifact of changes in the organizational form through which business income is reported. We now quantify how much of the rise in top pass-through income is in fact a real economic phenomenon. Online Appendix H.3 contains additional detail.

To correct for the effect of differential net entry into the pass-through sector, we construct a counterfactual pass-through profit series that assumes the level of pass-through sales remains a constant share of total business sales (including S-corporations, C-corporations, and partnerships) throughout the time period. In 2014, the share of profit levels due to organizational form changes is approximately $26 \%$, while $74 \%$ of pass-through profits remain under the constant share assumption. In terms of growth, actual top $0.1 \%$ profits increased $240 \%$ between 2001 and 2014 in real terms, while counterfactual profits rose 178\%. Thus, most of the growth in top profits remains after adjusting for organizational form reorganization. ${ }^{57}$ We note for the next subsection that although we adjust the level of pass-through income of organizational-form changes, we make no adjustments for any compositional effects.

\subsection{How is Entrepreneurial Income Rising? Productivity vs. Re- distribution}

Investigating the relative contributions of the growth and distribution of income can shed light on how entrepreneurial income has increased in recent years. Entrepreneurial income growth can come from two sources: growth in value added and growth in owners' share of value added. Value added growth can support explanations that emphasize technological progress, and owner share growth can support explanations that emphasize zero-sum compensation bargaining. A combination of value added growth and owner share growth could also reflect, in part, managerial-skill-biased technological change. For example, an increase in the output elasticity of owner labor or network connections would result in both more value added and a larger owner share.

We can decompose the overall growth in entrepreneurial income $I$ into value added growth

\footnotetext{
${ }^{57}$ We consider an alternative approach to measuring the role of organizational form switching using the population of businesses that switch from C-corporation to S-corporation form between 2001 and 2014 . We find that $70 \%$ of the growth in S-corporation profits is due to firms that did not switch from C-corporation form during this time.
} 
and redistribution to owners:

$$
\Delta I=\overbrace{\underbrace{\Delta \frac{V A}{L}}_{\text {Labor Productivity }}+\underbrace{\Delta L}_{\text {Scale }}}^{\text {Value Added Growth }}+\overbrace{\Delta s_{\text {owner }}}^{\text {Redistribution }} .
$$

where $\Delta X$ denotes the log change in $X$, value added growth sums growth in labor productivity and scale, and $s_{\text {owner }}$ is the share of value added that accrues to owners in either the form of owner wages or profits. We measure labor productivity as value added per worker, where value added equals profits plus W-2 wages and where the number of workers equals the number of $\mathrm{W}-2 \mathrm{~s}$ issued by the firm. We measure scale as the number of workers. ${ }^{58}$

Figure 10 presents data on the creation and distribution of income in the pass-through sector among firms with top owners. Figures 10A and 10B focus on the components of value added growth. Figure 10A shows how labor productivity (measured as value added per worker) and entrepreneurial income per worker have evolved since 2001. Figure 10B shows how the aggregate number of workers employed by top pass-throughs has evolved since 2001. We also present an adjusted series to account for organizational form switching. Following the analysis in Section 5.1, the adjusted series scales actual employment by a factor equal to the pass-through sales share of total business sales in 2001 divided by the contemporaneous pass-through sales share. For example, in 2014, this procedure reduces employment growth since 2001 by $24 \%$.

Labor productivity of top-owned firms has grown substantially from $\$ 33 \mathrm{~K}$ to $\$ 43 \mathrm{~K}$. This increase in value added per worker is consistent with explanations of top pay growth that emphasize technological progress, demand-driven growth in the service sector, or higher markups. Entrepreneurial income has tracked the evolution of labor productivity closely, suggesting that an important part of overall top entrepreneurial income growth is due to these drivers of value added growth. Aggregate pass-through employment has increased more modestly and fluctuates considerably with the business cycle. Adjusting for organizational form changes leaves the size of the workforce in top-owned firms essentially unchanged from 2001 to 2014. This pattern contrasts with the strong growth in top-owned profits even after adjusting for organizational form changes. Increasing profits without commensurate employment growth is consistent with the recent pattern of "scale without mass" observed in large public firms (Brynjolfsson, McAfee, Sorell and Zhu, 2008; Autor, Dorn, Katz, Patterson

\footnotetext{
${ }^{58}$ Gabaix and Landier (2008) emphasize firm size of competing firms as an important driver of CEO pay growth. Online Appendix Table J.10 implements a similar firm-level analysis to theirs. We find that top entrepreneurial income is increasing in firm size, but own-firm size is more important than the reference firm. These results suggest that top entrepreneurial income strongly depends on how large their firms are, but somewhat less on factors that influence the market for CEO pay of the largest firms in the economy.
} 
and Van Reenen, 2017).

Figure 10C uses equation (3) to divide the total growth in top entrepreneurial income into contributions from growth in value added per worker, in the entrepreneurial income share of value added, and in total employment adjusted for organizational form changes. We measure these changes as the growth from the level in 2001 to the level in 2014. As there was a recession in 2001 and not in 2014, we also show the growth from the level in 2004.

For top $1 \%$ pass-throughs, value added per worker, employment, and the owner share increased by $25.3 \%,-9.7 \%$, and $24.5 \%$, respectively, from 2001 to 2014, after adjusting this employment growth for organizational form changes. ${ }^{59}$ Thus, $63 \%$ of the growth in top $1 \%$ entrepreneurial income (equal to $(25.3 \%) /(25.3 \%-9.7 \%+24.5 \%))$ comes from rising labor productivity, $-24 \%$ comes from lower employment, and the remaining $61 \%$ comes from a growing owner share of value added. Overall growth for top $0.1 \%$ firms was larger, though the relative contributions from productivity and entrepreneurial income are similar. ${ }^{60}$ Using 2004 as the reference year modestly increases the importance of labor productivity growth, but the results are similar.

Figure 10D shows that the share of value added going to non-owner workers fell substantially among top-owned pass-throughs from 2001 to 2014. Over this period, the owner share increased from $37 \%$ to $48 \%$ of value added for top $1 \%$ firms and from $40 \%$ to $52 \%$ for top $0.1 \%$ firms. The figure also shows how the composition of entrepreneurial income evolved over this time period, with owners paying themselves less in wages and more in profits. The share of value added going to owners in the form of wages fell by 1.9 percentage points for top-owned firms. Thus, interpreting the fall of wage income in value added as reflecting income lost by workers would overstate the decline in the labor share; some of the fall reflects the rise of recharacterized owner wages.

Overall, growth in entrepreneurial income is explained by both rising labor productivity and a rising share of value added accruing to owners. In contrast, after accounting for the growth due to organizational form changes, rising firm scale in the form of employment plays no role in the growth of top entrepreneurial income. Economic explanations that emphasize growing the pie, rather than zero-sum bargaining over its distribution, are necessary to fit the facts. Yet such explanations would be incomplete without rationalizing how, as labor productivity grows, owner-managers appear to capture an increasing share.

\footnotetext{
${ }^{59}$ The unadjusted employment growth is $23.1 \%$.

${ }^{60}$ Specifically, $61 \%$ of the overall top $0.1 \%$ pay growth comes from rising labor productivity, $-16 \%$ comes from lower employment, and $56 \%$ comes from owner share growth.
} 


\section{Conclusion}

We have used de-identified U.S. tax records, including novel linked firm-owner-worker data, to investigate the importance of human capital at the top of the U.S. income distribution. The data reveal a striking world of business owners who prevail at the top of the income distribution. We find that most private business profits reflect the return to owner human capital. Overall, top earners are predominantly human-capital rich, and the majority of top income accrues to the human capital of wage earners and entrepreneurs, not financial capital.

We highlight three directions for future research. First, the presence and growth of recharacterized labor income mechanically reduces the measured labor share in the U.S. corporate sector. More broadly, economic measurement of labor and capital income depends upon the incentives and reporting structure of the tax system. Future research on top inequality should continue to engage with the role of entrepreneurial income amid a realworld environment of changing tax policy, including by investigating the human capital component of other forms of capital income such as C-corporation income and rental income. To the extent that labor income is characterized as capital income, there may be a rationale for aligning capital and labor income tax rates (Piketty and Saez, 2013).

Second, linking C-corporations to their owners would improve measurement of top income and wealth inequality. We have provided an online appendix that explores various methods of allocating C-corporation retained earnings, which can be used to improve corporate wealth estimates in the absence of direct ownership data. Linking unreported profits from unincorporated businesses to their owners would also improve measurement. Top wealth estimates based on capitalized income flows and a constant returns assumption can be improved by accounting for the higher profitability of top-owned firms.

Third, much of rising top income inequality remains consistent with rising private returns to top human capital, but we stress that our findings are silent on the social value of those returns. For example, private returns to owner-manager factors can exceed social returns due to rent-seeking, elite connections, and unequal access to the opportunity to enter certain professions, industries, or markets. Normative conclusions about the social value of top human capital therefore require data and assumptions beyond the scope of this paper. Future research should investigate the link between private and social returns, an important next step in explaining their evolution and assessing policy implications.

US Treasury Department

UC Berkeley and NBER

Princeton and NBER

Chicago Booth and NBER 


\section{References}

Abowd, John, Francis Kramarz, and David Margolis. 1999. "High Wage Workers and High Wage Firms." Econometrica, 67(2): 251-333.

Alstadsaeter, Annette, Martin Jacob, Wojciech Kopczuk, and Kjetil Telle. 2016. "Accounting for Business Income in Measuring Top Income Shares: Integrated Accrual Approach Using Individual and Firm Data from Norway." National Bureau of Economic Research Working Paper 22888.

Atkinson, Anthony Barnes, and Joseph E Stiglitz. 1976. "The design of tax structure: direct versus indirect taxation." Journal of public Economics, 6(1-2): 55-75.

Auten, Gerald, and David Splinter. 2018. "Using Tax Data to Measure Long-Term Trends in U.S. Income Inequality." Treasury Office of Tax Analysis Working Paper.

Auten, Gerald, David Splinter, and Susan Nelson. 2016. "Reactions of High-Income Taxpayers to Major Tax Legislation." National Tax Journal, 69(4): 935.

Autor, David, David Dorn, Lawrence F Katz, Christina Patterson, and John Van Reenen. 2017. "The Fall of the Labor Share and the Rise of Superstar Firms." National Bureau of Economic Research Working Paper 23396.

Autor, David H., Frank Levy, and Richard J. Murnane. 2003. "The skill content of recent technological change: An empirical exploration." Quarterly Journal of Economics, 118(4): 1279-1333.

Autor, David H, Lawrence F Katz, and Melissa S Kearney. 2008. "Trends in US Wage Inequality: Revising the Revisionists." Review of Economics and Statistics, 90(2): 300-323.

Bakija, Jon, Adam Cole, and Bradley T. Heim. 2012. "Jobs and income growth of top earners and the causes of changing income inequality: Evidence from US tax return data." Working Paper, Williams College.

Becker, Sascha, and Hans Hvide. 2017. "Do entrepreneurs matter?" Working Paper.

Bennedsen, Morten, Francisco Perez-Gonzalez, and Daniel Wolfenzon. 2010. "Do CEOs Matter?"

Bennedsen, Morten, Francisco Perez-Gonzalez, and Daniel Wolfenzon. 2012. "Estimating the Value of The Boss: Evidence from CEO Hospitalization Events."

Bennedsen, Morten, Kasper Meisner Nielsen, Francisco Pérez-González, and Daniel Wolfenzon. 2007. "Inside the family firm: The role of families in succession decisions and performance." Quarterly Journal of Economics, 122(2): 647-691.

Bhandari, Anmol, and Ellen R McGrattan. 2018. "Sweat Equity in US Private Business." National Bureau of Economic Research \#24520. 
Bricker, Jesse, Alice Henriques, Jacob Krimmel, and John Sabelhaus. 2016. "Measuring income and wealth at the top using administrative and survey data." Brookings Papers on Economic Activity, 2016(1): 261-331.

Brynjolfsson, Erik, Andrew McAfee, Michael Sorell, and Feng Zhu. 2008. "Scale Without Mass: Business Process Replication and Industry Dynamics." HBS Working Paper 07-016.

Caballero, Ricardo J, Emmanuel Farhi, and Pierre-Olivier Gourinchas. 2017. "Rents, Technical Change, and Risk Premia Accounting for Secular Trends in Interest Rates, Returns on Capital, Earning Yields, and Factor Shares." American Economic Review, 107(5): 614-20.

Card, David, Jörg Heining, and Patrick Kline. 2013. "Workplace heterogeneity and the rise of West German wage inequality." Quarterly Journal of Economics, 128(3): 9671015.

Chamley, Christophe. 1986. "Optimal taxation of capital income in general equilibrium with infinite lives." Econometrica: Journal of the Econometric Society, 607-622.

Chetty, Raj, and Emmanuel Saez. 2005. "Dividend Taxes and Corporate Behavior: Evidence from the 2003 Dividend Tax Cut." Quarterly Journal of Economics, 120(3): 791.

Chetty, Raj, John N Friedman, Emmanuel Saez, Nicholas Turner, and Danny Yagan. 2019. "Income Segregation and Intergenerational Mobility Across Colleges in the United States." national bureau of economic research.

Chetty, Raj, Nathaniel Hendren, Patrick Kline, and Emmanuel Saez. 2014. "Where is the land of opportunity? The geography of intergenerational mobility in the United States." Quarterly Journal of Economics, 129(4): 1553-1623.

Clarke, Conor, and Wojciech Kopczuk. 2017. "Business Income and Business Taxation in the United States since the 1950s." Tax Policy and the Economy, 31(1): 121-159.

Cooper, Michael, John McClelland, James Pearce, Richard Prisinzano, Joseph Sullivan, Danny Yagan, Owen Zidar, and Eric Zwick. 2016. "Business in the United States: Who Owns It, and How Much Tax Do They Pay?" Tax Policy and the Economy, 30(1): 91-128.

DeBacker, Jason M, and Richard Prisinzano. 2015. "The Rise of Partnerships." Tax Notes, 147(13): 1563-75.

De Loecker, Jan, and Jan Eeckhout. 2017. "The Rise of Market Power and the Macroeconomic Implications." National Bureau of Economic Research Working Paper 22822.

Dyrda, Sebastian, and Benjamin Pugsley. 2018. "Taxes, Regulations of Businesses and Evolution of Income Inequality in the US." University of Toronto Working Paper. 
Edmans, Alex, and Xavier Gabaix. 2016. "Executive compensation: A modern primer." Journal of Economic Literature, 54(4): 1232-1287.

Fagereng, Andreas, Luigi Guiso, Davide Malacrino, and Luigi Pistaferri. 2016. "Heterogeneity and persistence in returns to wealth." National Bureau of Economic Research Working Paper 22822.

Fisman, Raymond. 2001. "Estimating the value of political connections." American Economic Review, 91(4): 1095-1102.

Foster, Lucia, John Haltiwanger, and Chad Syverson. 2008. "Reallocation, Firm Turnover, and Efficiency: Selection on Productivity or Profitability?" American Economic Review, 98(1): 394-425.

Gabaix, Xavier, and Augustin Landier. 2008. "Why has CEO pay increased so much?" Quarterly Journal of Economics, 123(1): 49-100.

Goldin, Claudia Dale, and Lawrence F Katz. 2009. The Race between Education and Technology. Harvard University Press.

Gordon, Roger, and Joel Slemrod. 2000. "Are 'Real' Responses to Taxes Simply Income Shifting between Corporate and Personal Tax Bases (New York: Russell Sage Foundation; Cambridge, MA: Harvard University Press, 2000)." In Does Atlas Shrug? The Economic Consequences of Taxing the Rich. , ed. Joel Slemrod, Chapter 8, 240-288. Cambridge:Russell Sage Foundation Books at Harvard University Press.

Gordon, Roger H., and Jeffrey K. MacKie-Mason. 1994. "Tax distortions to the choice of organizational form." Journal of Public Economics, 55(2): 279-306.

Hall, Robert E. 1988. "The relation between price and marginal cost in US industry." Journal of Political Economy, 96(5): 921-947.

Hsieh, Chang-Tai, and Peter Klenow. 2009. "Misallocation and Manufacturing TFP in China and India." Quarterly Journal of Economics, 124(4): 1403-1448.

Jäger, Simon. 2016. "How Substitutable Are Workers? Evidence from Worker Deaths." Working Paper, Massachusetts Institute of Technology.

Jaravel, Xavier, Neviana Petkova, and Alex Bell. 2018. "Team-Specific Capital and Innovation." American Economic Review, 108(4-5): 1034-73.

Johnson, W Bruce, Robert P Magee, Nandu J Nagarajan, and Harry A Newman. 1985. "An analysis of the stock price reaction to sudden executive deaths: Implications for the managerial labor market." Journal of Accounting and Economics, 7(1-3): 151-174.

Judd, Kenneth L. 1985. "Redistributive taxation in a simple perfect foresight model." Journal of public Economics, 28(1): 59-83.

Kaplan, Steven N, and Joshua Rauh. 2013. "It's the market: The broad-based rise in the return to top talent." Journal of Economic Perspectives, 27(3): 35-55. 
Karabarbounis, Loukas, and Brent Neiman. 2014. "The Global Decline of the Labor Share." Quarterly Journal of Economics, 129(1): 61-103.

Katz, Lawrence F, and Kevin M Murphy. 1992. "Changes in relative wages, 1963-1987: supply and demand factors." Quarterly Journal of Economics, 107(1): 35-78.

Khwaja, Asim Ijaz, and Atif Mian. 2005. "Do lenders favor politically connected firms? Rent provision in an emerging financial market." Quarterly Journal of Economics, 120(4): 1371-1411.

Kopczuk, Wojciech, and Emmanuel Saez. 2004. "Top Wealth Shares in the United States, 1916-2000: Evidence From Estate Tax Returns." National Tax Journal, 57(2): 44587.

Kotlikoff, Laurence J, and Lawrence H Summers. 1981. "The role of intergenerational transfers in aggregate capital accumulation." Journal of political economy, 89(4): 706-732.

Krueger, Anne O. 1974. "The political economy of the rent-seeking society." American Economic Review, 64(3): 291-303.

Kuziemko, Ilyana, Michael I Norton, Emmanuel Saez, and Stefanie Stantcheva. 2015. "How elastic are preferences for redistribution? Evidence from randomized survey experiments." American Economic Review, 105(4): 1478-1508.

Mackie-Mason, Jeffrey K., and Roger H. Gordon. 1997. "How much do taxes discourage incorporation?" Journal of Finance, 52(2): 477-506.

Modigliani, Franco. 1986. "Life Cycle, Individual Thrift, and the Wealth of Nations." The American Economic Review, 76(3): 297-313.

Murphy, Kevin M, Andrei Shleifer, and Robert W Vishny. 1991. "The Allocation of Talent: Implications for Growth." Quarterly Journal of Economics, 106(2): 503-530.

Murphy, Kevin M, and Robert H Topel. 2016. "Human capital investment, inequality, and economic growth." Journal of Labor Economics, 34(S2): S99-S127.

Nelson, Susan C. 2016. "Paying Themselves: S Corporation Owners and Trends in S Corporation Income, 1980-2013." OTA Working Paper $10 \%$.

Pérez-González, Francisco. 2006. "Inherited Control and Firm Performance." American Economic Review, 96(5): 1559-1588.

Piketty, Thomas. 2011. "On the Long-Run Evolution of Inheritance: France 1820-2050." Quarterly Journal of Economics, 126(3): 1071-1131.

Piketty, Thomas. 2014. Capital in the 21st Century. Cambridge, MA:Harvard University Press.

Piketty, Thomas, and Emmanuel Saez. 2003. "Income Inequality in the United States, 1913-1998." Quarterly Journal of Economics, 118(1): 1-41. 
Piketty, Thomas, and Emmanuel Saez. 2013. "Optimal labor income taxation." In Handbook of public economics. Vol. 5, 391-474. Elsevier.

Piketty, Thomas, and Gabriel Zucman. 2014. "Capital is Back: Wealth-Income Ratios in Rich Countries, 1700-2010." Quarterly Journal of Economics, 129(3): 1255-1310.

Piketty, Thomas, Emmanuel Saez, and Gabriel Zucman. 2018. "Distributional national accounts: methods and estimates for the United States." The Quarterly Journal of Economics, 133(2): 553-609.

Piketty, Thomas, Emmanuel Saez, and Stefanie Stantcheva. 2014. "Optimal Taxation of Top Labor Incomes: A Tale of Three Elasticities." American Economic Journal: Economic Policy, 6(1): 230-71.

Piketty, Thomas, Gilles Postel-Vinay, and Jean-Laurent Rosenthal. 2014. "Inherited vs self-made wealth: Theory \& evidence from a rentier society (Paris 1872-1927)." Explorations in economic history, 51: 21-40.

Prisinzano, Richard, and James Pearce. 2017. "Tax Based Switching of Business Income."

Rognlie, Matthew. 2016. "Deciphering the Fall and Rise in the Net Capital Share: Accumulation or Scarcity?" Brookings Papers on Economic Activity, 2016(1): 1-69.

Saez, Emmanuel, and Gabriel Zucman. 2016. "Wealth inequality in the United States since 1913: Evidence from capitalized income tax data." Quarterly Journal of Economics, 131(2): 519-578.

Slemrod, Joel. 1996. "High Income Families and the Tax Changes of the 1980s: The Anatomy of Behavioral Response." In Empirical Foundations of Household Taxation. Vol. 118, , ed. Martin Feldstein and James M Poterba, Chapter 6, 169-192. Chicago:University of Chicago Press.

Smith, Matthew, Danny Yagan, Owen Zidar, and Eric Zwick. 2017. "Capitalists in the Twenty-first Century." UC Berkeley and University of Chicago Working Paper.

Song, Jae, David Price, Fatih Guvenen, Nicholas Bloom, and Till von Wachter. forthcoming. "Firming Up Inequality." Quarterly Journal of Economics.

Syverson, Chad. 2011. "What Determines Productivity?" Journal of Economic Literature, 49(2): 326-65.

Yagan, Danny. 2015. "Capital Tax Reform and the Real Economy: The Effects of the 2003 Dividend Tax Cut." American Economic Review, 105(12): 3531-3563.

Zimmerman, Seth D. forthcoming. "Elite Colleges and Upward Mobility to Top Jobs and Top Incomes." American Economic Review.

Zwick, Eric, and James Mahon. 2017. "Tax Policy and Heterogeneous Investment Behavior." American Economic Review, 107(1): 217-48. 
Figure 1: Income Sources of Top Earners in 2014

A. Share of People by Majority Income Source

Fiscal Income (FI)

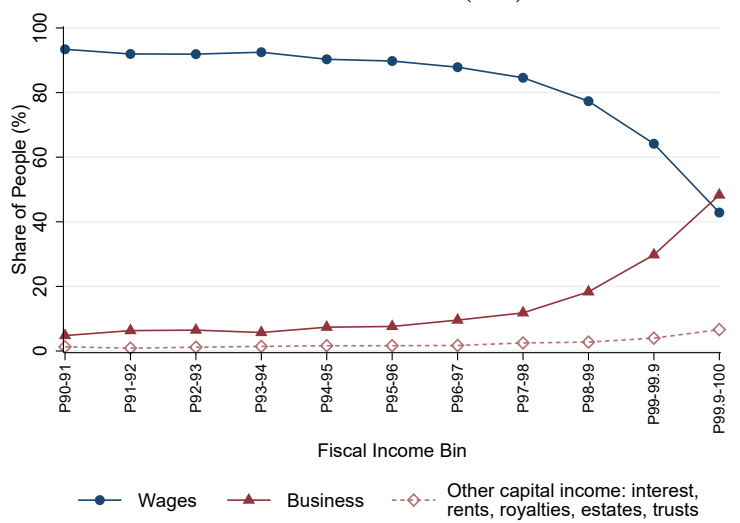

Imputed National Income (INI)

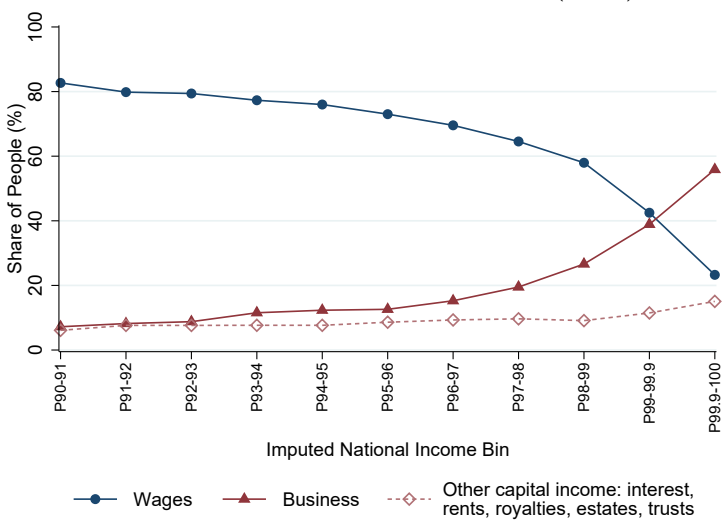

B. Share of Income by Source

Fiscal Income (FI)

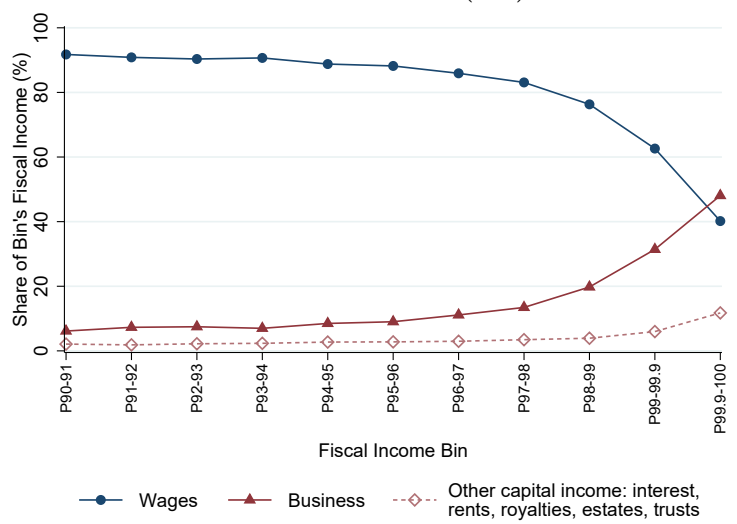

C. Share of Income by Business Income Source

Fiscal Income (FI)

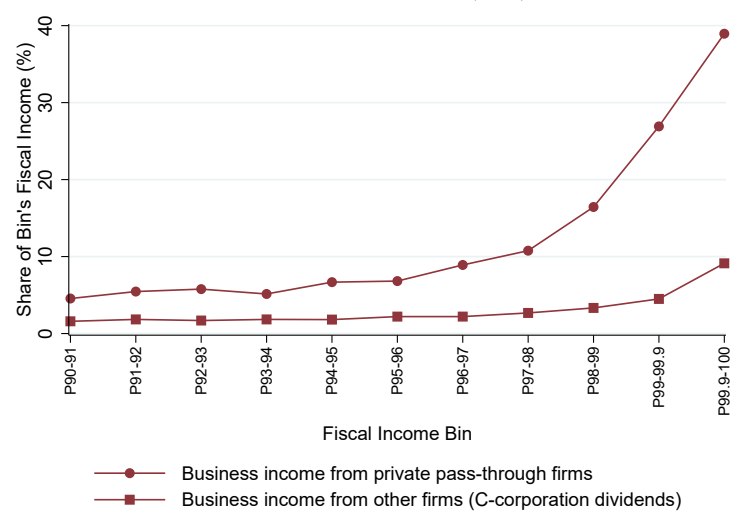

Imputed National Income (INI)

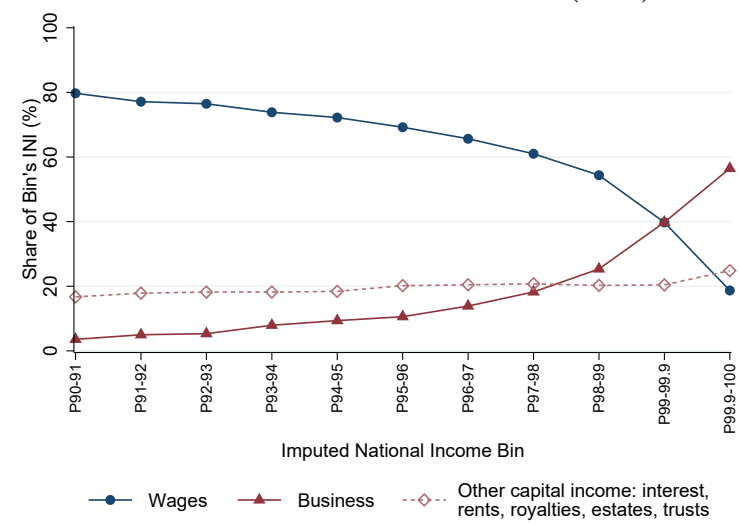


Notes to Figure 1: This figure uses our 2014 top-incomes data to show the relative importance of different income sources for top earners using fiscal income (i.e., directly observed tax data) and imputed national income. Panel A plots the share of tax units (fiscal income) or adult individuals (imputed national income) in each income bin who earned the majority of their income in 2014 from wages, business income, or other capital income. For fiscal income, wages includes wages-salaries-and-tips, pension distributions, and annuities, as in Piketty and Saez (2003); business income includes pass-through income (S-corporation income, partnership income, and sole proprietor's income) and C-corporation dividends; other capital income includes all other income sources (interest, rents, royalties, and estate and trust income). For imputed national income, we use analogous definitions from Piketty, Saez and Zucman (2018), which includes imputed employerprovided health insurance (included in wages), imputed rents from owner-occupied housing (included in other capital income), and imputed C-corporation retained earnings (included in business income) among other components of national income that do not appear on tax returns. Panel B plots the share of total top income in the form of wages, business, and other capital income for each income bin. Panel $\mathrm{C}$ separates the business income series into contributions from pass-through business and C-corporation income.

Figure 2: Working-Age Pass-Through Owners Prevail at the Top of the Income Distribution

A. Pass-Through Income in Top 1\% is Large

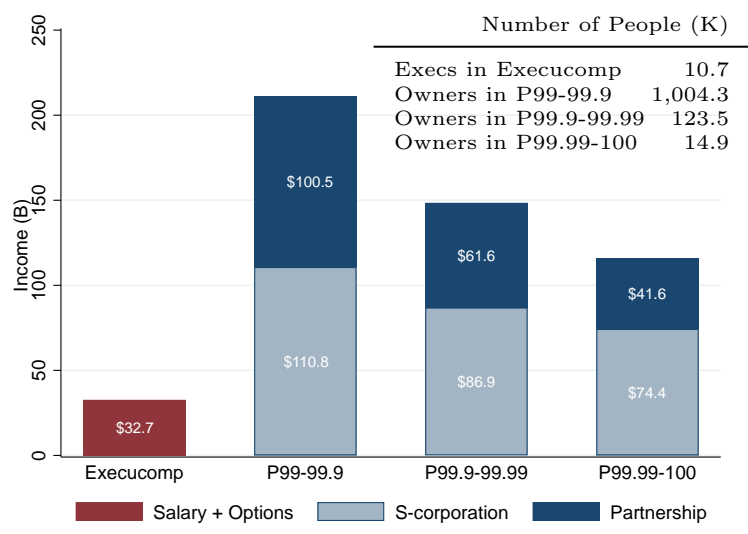

B. Millionaire Pass-through Owners are Working Age

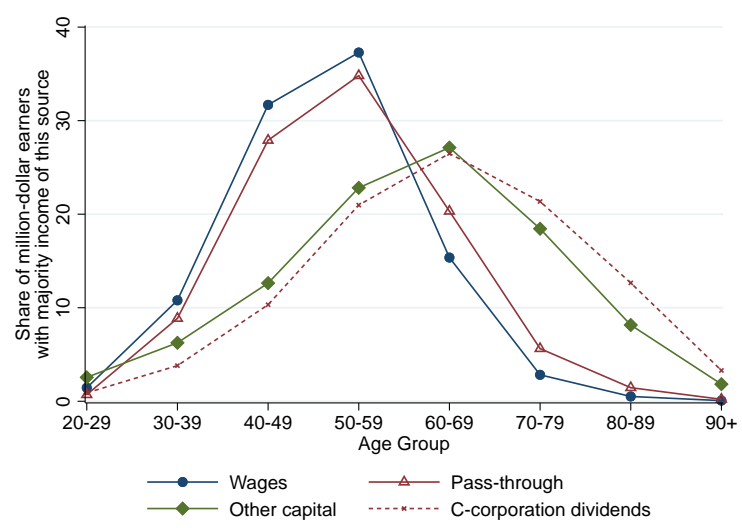

Notes: Panel A uses our 2014 top incomes data to plot the aggregate pass-through income within the top $1 \%$ by fiscal income bin and compares that quantity to aggregate salary plus options compensation for all executives in the Execucomp database in 2014. Panel B uses our 2014 top incomes data to plot the share of tax units with over one million dollars in fiscal income who earn the majority of their fiscal income in 2014 from either wages, pass-through income, C-corporation dividends, or other capital income by age (i.e., the age of the single tax filer or the mean age of married spouses filing jointly). 
Figure 3: Top-Owned Firms Are Mid-Market and Broad-Based across Industries
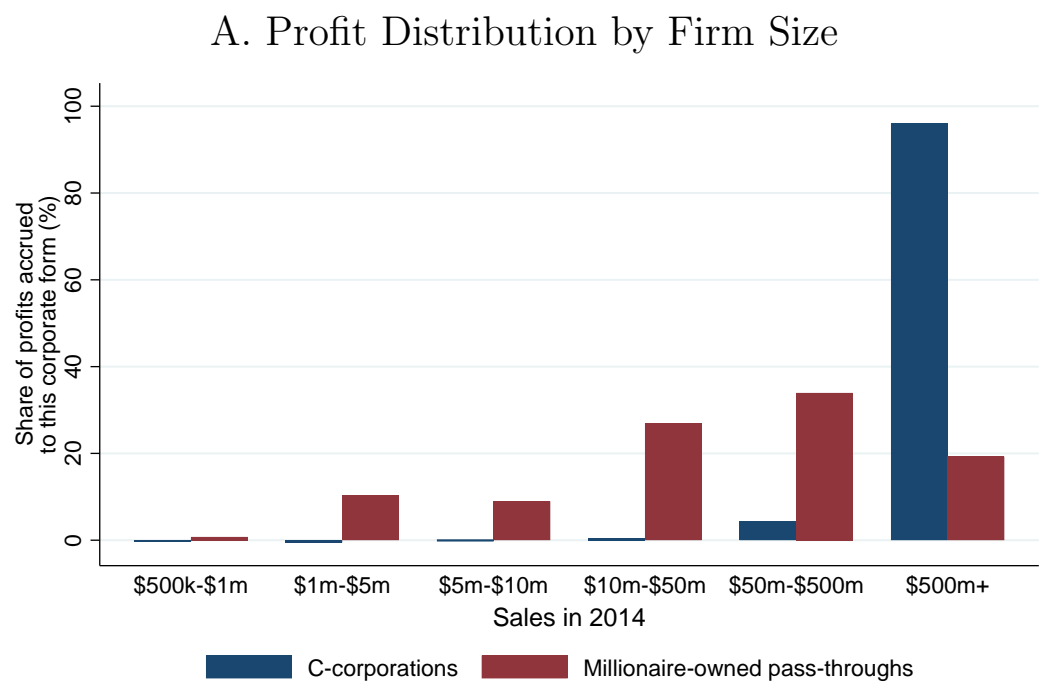

B. Distribution of Profits Across Industries

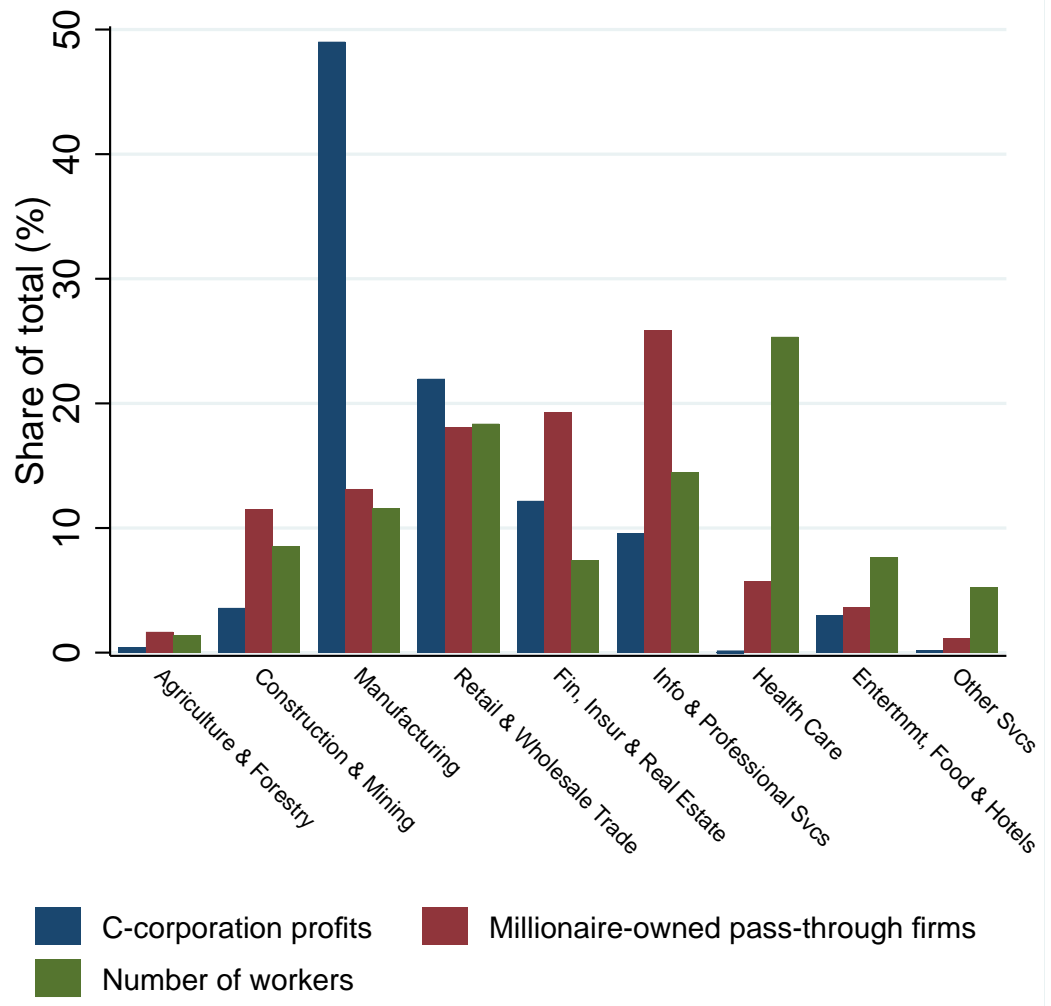

Notes: This figure uses our 2014 linked-firm-owner data and our SOI C-corporation data to plot the distribution of profits by firm size and industry in 2014 by organizational form. Panel A plots the distribution of aggregate profits by firm sales for C-corporations, and separately for pass-throughs owned by tax units with at least one million dollars in fiscal income. Panel B plots the distribution of profits generated by each organizational form across 1-digit NAICS sectors. We split NAICS 5 into two sub-categories: Finance, Insurance and Real Estate (FIRE), which encompasses NAICS codes 52 and 53; and Information and Professional Services, which includes NAICS 51, 54 and 56. Since NAICS 55 (Management of Companies and Enterprises, i.e., holding companies) includes activity from several industries, we exclude it here. See Online Appendix Figure I.3 for versions with top 1\% and top 0.1\% pass-through owners. 


\section{Figure 4: Profitability Rises with Owner Income Rank}

A. Profits per Worker by Owner Income Rank

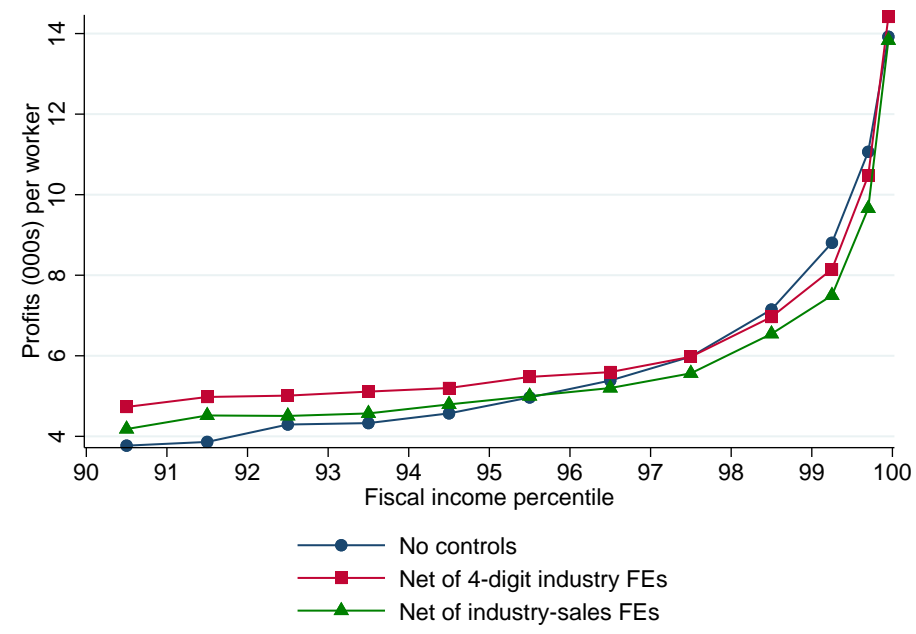

B. Profits per worker in Startup's First Five Years

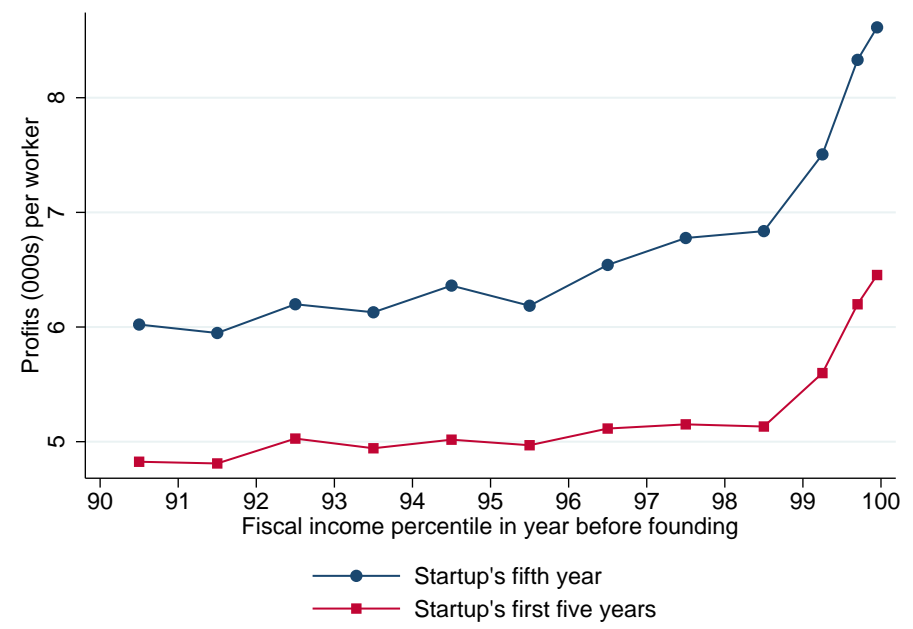

Notes: Panel A plots firm profitability (profits per worker) by owner fiscal income across owner-firm observations in the 2014 linked-firm-owner data. The bins are one-percentile-point wide in fiscal income, except in the top $1 \%$ where we consider bins of ranks between the 99th percentile and 99.5th percentile, the 99.5th percentile and 99.9th percentile, and the top $0.1 \%$. Means are weighted by scale (the firm's number of workers). Industry fixed effects denote 4-digit NAICS indicators. Sales fixed effects denote ventile indicators (i.e., five-percentile-point bins in the firm sales distribution). Panel B plots the equivalent of Panel A's within-industry series using the population of pass-through startups 2001-2010. It ranks owners by their fiscal income in the year before founding a new pass-through. It plots in blue circles profits per worker in the firm's fifth year of existence, conditional on the firm surviving five years. It plots in red squares the startup's sum of its first five years of annual profits divided by the startup's sum of its first five years of annual number of workers, imputing zeros for profits and workers in years after a startup exits. We focus on firms with positive workers. We winsorize profitability at the 1st and 99th percentiles across the year's top-decile owner-firm observations. We apportion profits and workers to owners according to ownership shares. To take out fixed effects, we compute profitability at the owner-firm level for all owners in the top personal income decile, regress profitability on industry fixed effects weighted by the number of workers, compute residuals, add a constant to the residuals such that the sum of the product of the residuals and the number of workers equals total profits, and then compute the employment-weighted mean of each bin's residuals. The addition of the constant ensures that the overall employment-weighted mean profitability is constant across specifications. 
Figure 5: Profit Impacts of Owner Deaths and Retirements

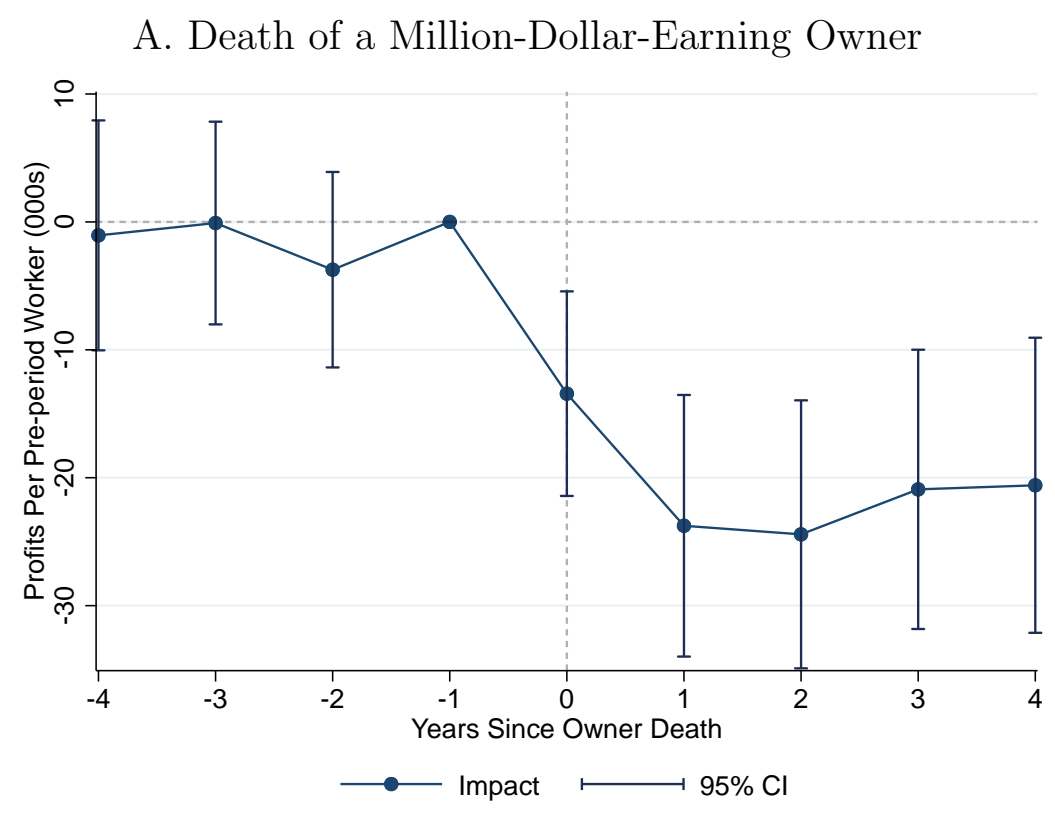

B. Retirement of a Million-Dollar-Earning Owner

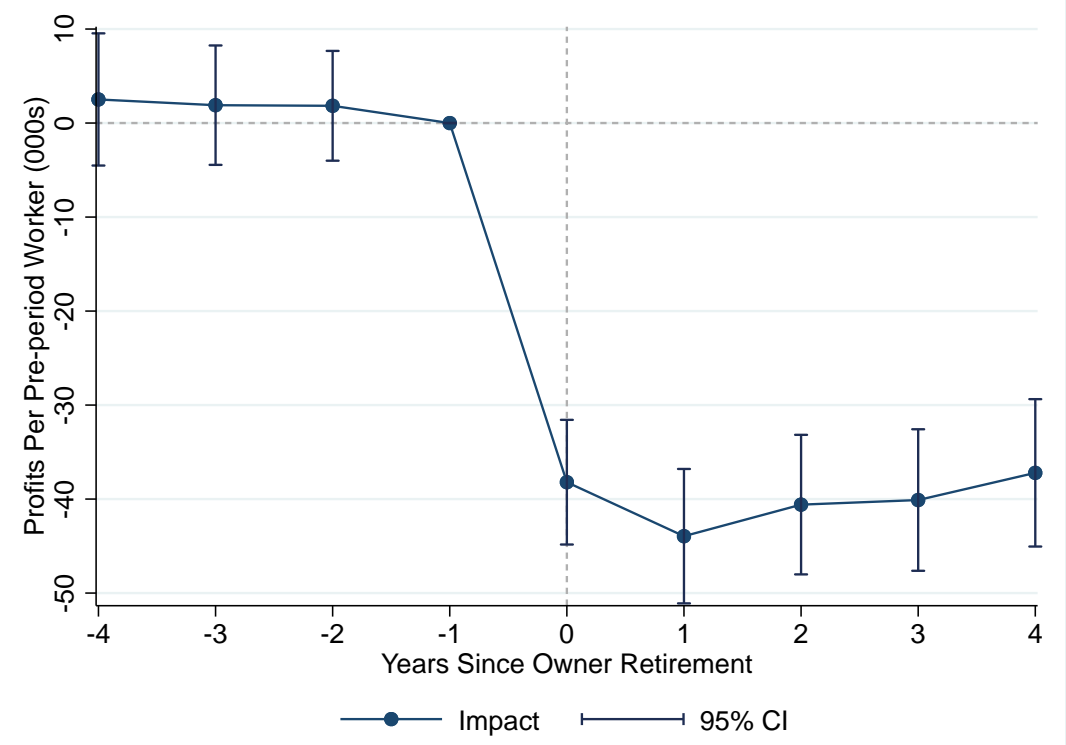

Notes: For Panel A, we identify all 765 "owner-death" firms in our linked-firm-owner-worker data that: (i) have an owner in a year $t \in[2005,2010]$ who was under age 65 , died in year $t$, and had over $\$ 1$ million in $t-1$ fiscal income; (ii) had no other owner deaths 2001-2014, at least $\$ 100,000$ in sales in 2014 dollars in $t-1$, positive sales in all years [t-4,t-1], and the firm had positive employment in some year $[t-4, t-1]$; and (iii) has at least one "counterfactual" firm of the same organizational form that met the same $[t-4, t-1]$ firm requirements, match the owner-death firm on three-digit industry and $t-1$ sales decile, and have a year- $t$ owner who matches the dying owner on $t-1$ income fractile and five-year age bin. For Panel B, we identify all 5,312 "owner-retirement" firms that satisfy requirements similar to those for owner-death firms except that instead of death, we measure retirement as the firm having at least one owner receiving W-2 wages in consecutive years $[t-4, t-1]$ and no one receiving wages $[t, t+1]$. Counterfactual firms had at least one owner receiving W-2 wages $[t-4, t+1]$. Each panel presents simple difference-in-difference estimates of the event (death or retirement) impact on annual firm profits $(\$ \mathrm{~K})$ per mean annual pre-period worker. Displayed $95 \%$ confidence intervals are based on standard errors clustered at the firm level. See Online Appendix Figures I.6 for analogous graphs for top $1 \%$ and top $0.1 \%$ owtiers. 
Figure 6: Impact of Organizational Form Switch on Profits and Wage Payments

A. All vs. Non-Majority-Owned

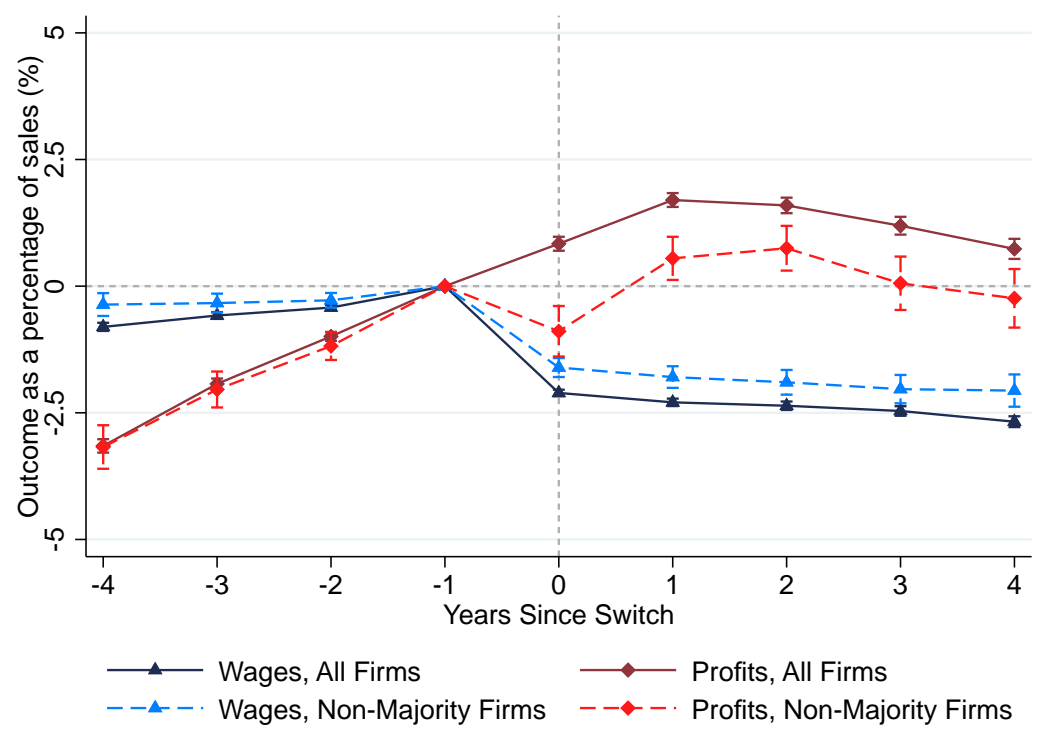

B. All vs. Skilled Service

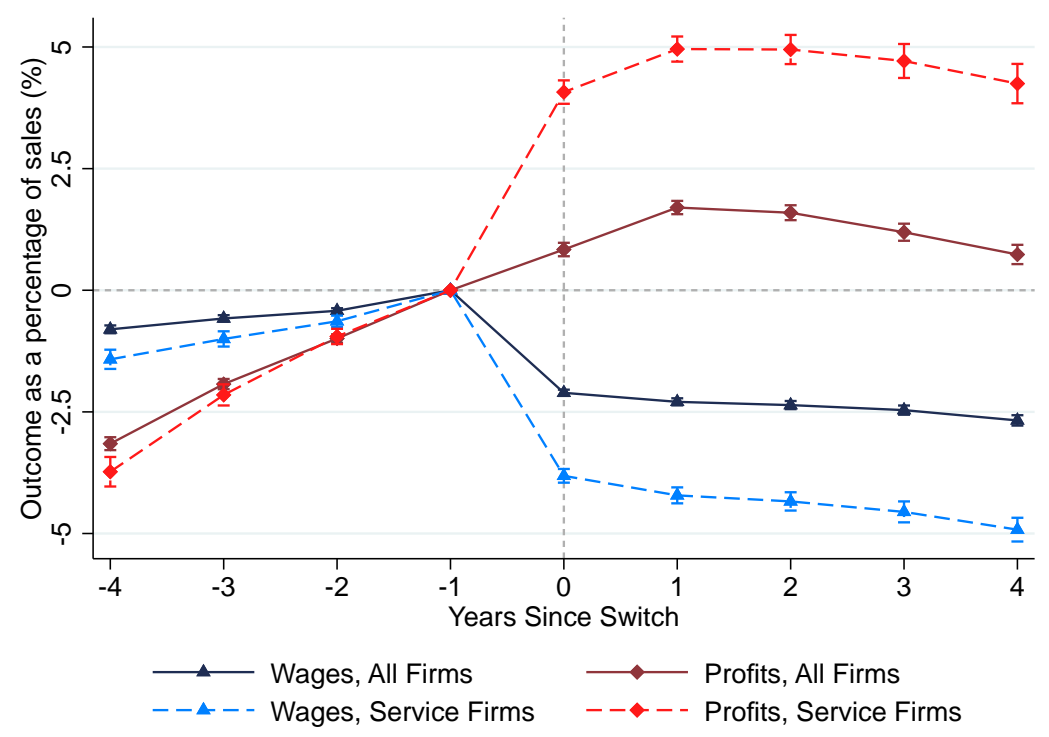

Notes: This figure uses our linked-firm-owner data to display how wage payments and profits change when a firm changes organizational form from C-corporation to S-corporation. The sample includes all 157,272 Scorporations that switched from C-corporate to S-corporate form between 2001-2010; had at least $\$ 100 \mathrm{~K}$ in sales in year prior to the switch; and were active in the four years before and four years following the switch. The No Majority series plot changes for the 14,600 firms that had only minority owners (i.e., with less than $50 \%$ ownership) in the switch year. The Service series plot changes for switch events for the 53,220 firms that were in high-skilled service industries, defined as having 2-digit NAICS $\in\{51,52,54,56,61,62\}$. We study two outcomes: annual profits divided by contemporaneous sales, and annual wage payments (including officer compensation) divided by contemporaneous sales. Each plotted series comprises difference estimates for the outcome of interest relative to $t-1$, conditional on firm and calendar year fixed effects. Displayed $95 \%$ confidence intervals are based on standard errors clustered at the firm level. 
Figure 7: Are Top Earners Human-Capital Rich?

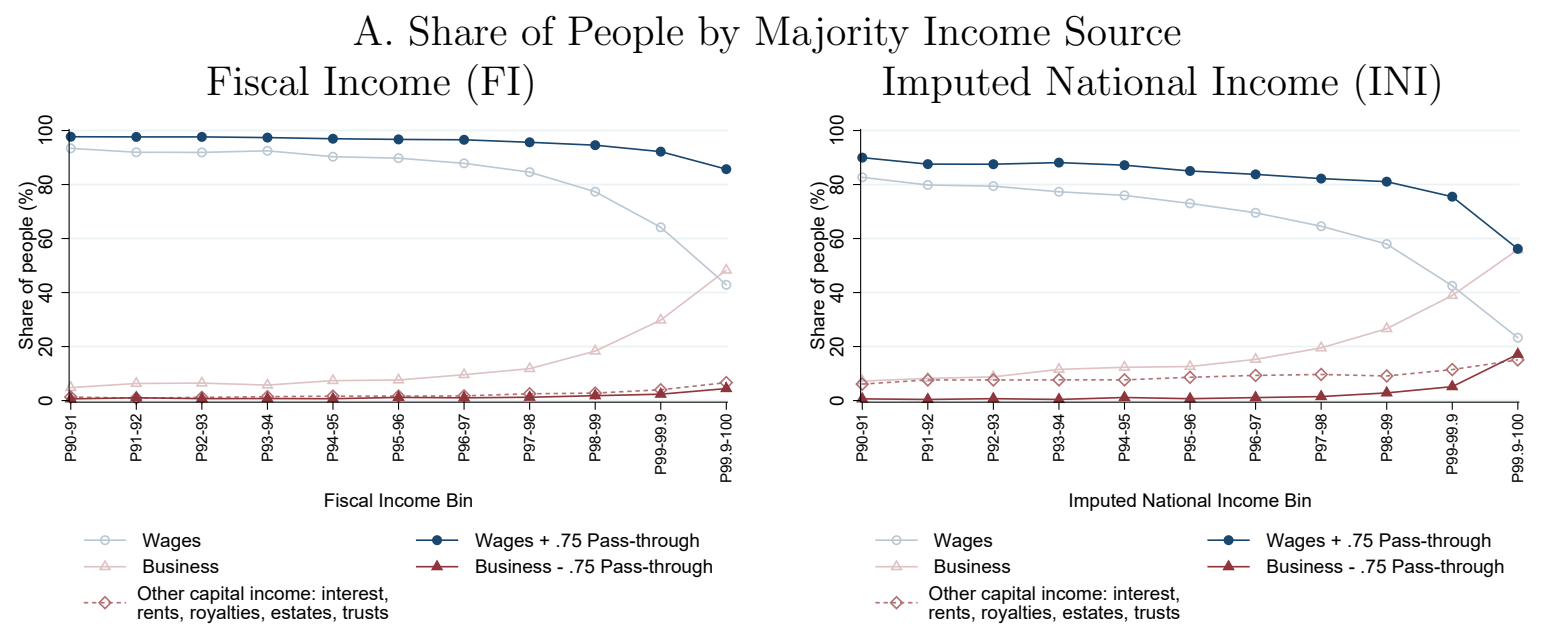

\section{B. Human-Capital Rich and Self-Made Shares of Top Earners Fiscal Income (FI) \\ Imputed National Income (INI)}
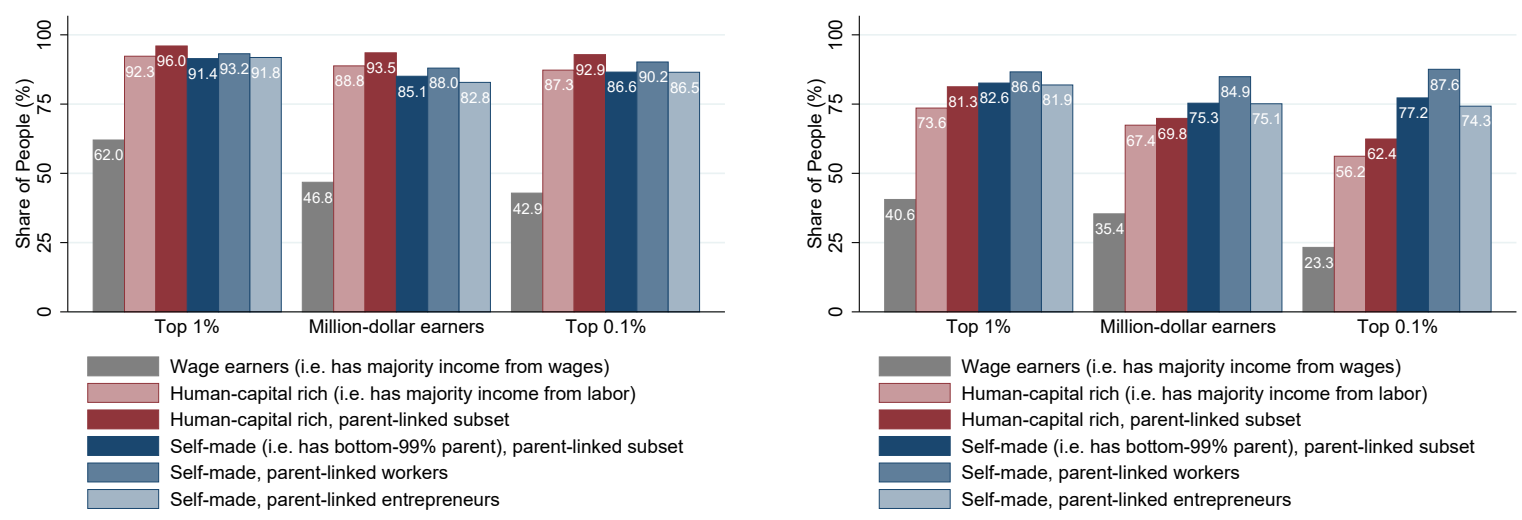

Notes: The left figure in Panel B uses our top incomes data to classify top earners (tax units) in the 2014 fiscal income series. The right figure in Panel B classifies top earners (individual) in the 2014 imputed national income series. Wage earners are those earning a majority of their income from wages. Humancapital rich are those earning a majority of their income from labor income, defined as wages plus $75 \%$ of pass-through income. The parent-linked subset comprises 32-34-year-olds who can be linked to parents. The Self-made bars plot the share of top earners in the indicated subset who had a parent earning in the bottom $99 \%$ of the income distribution. Entrepreneurs are earners who earned a majority of their income as pass-through entrepreneurial income, defined as pass-through income plus owner wages (i.e., W-2 wages earned from owned pass-throughs). 
Figure 8: How Do Top Earners Earn Their Income?

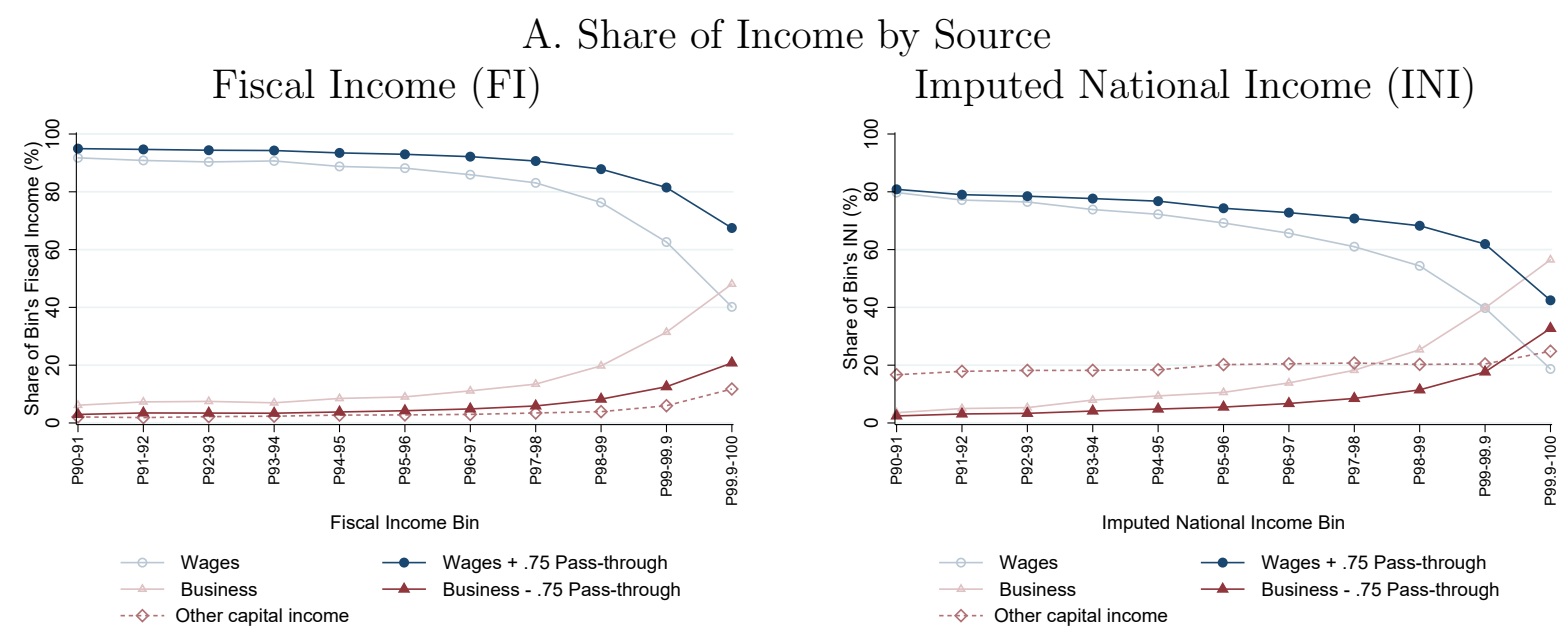

B. Top Labor and Capital Income

Fiscal Income (FI)

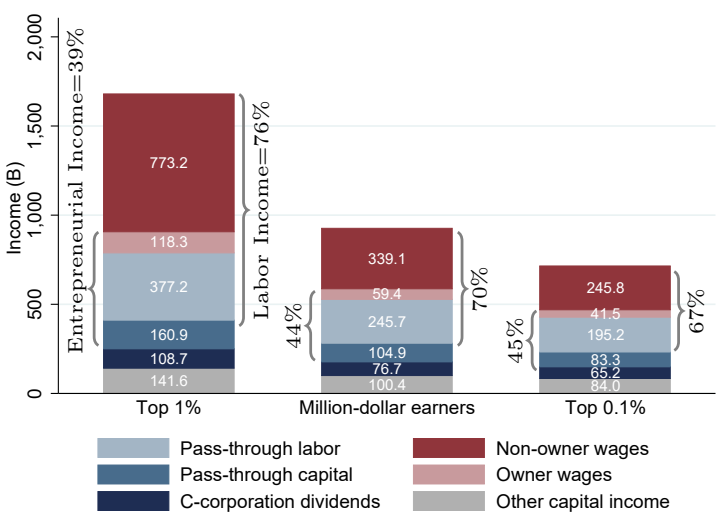

Imputed National Income (INI)

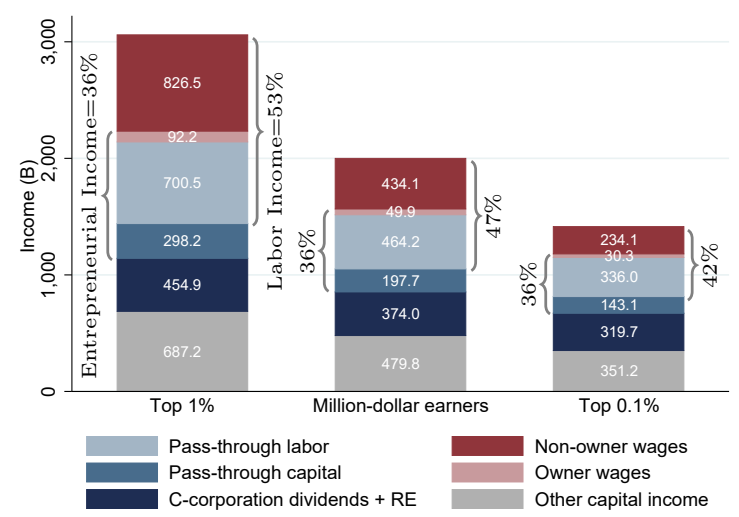

Notes: This figure uses our top incomes data to quantify sources of top incomes in 2014. Wages, pass-through income, and C-corporation income (dividends, or dividends and retained earnings), and other capital income are defined as in Figure 1. Pass-through labor income equals $75 \%$ of pass-through income; pass-through capital income equals the remainder of pass-through income. Owner wages equal W-2 wages paid to owners from pass-throughs they own; non-owner wages equal the remainder of wages. 
Figure 9: Business Income and Rising U.S. Income Inequality (1960-2014)
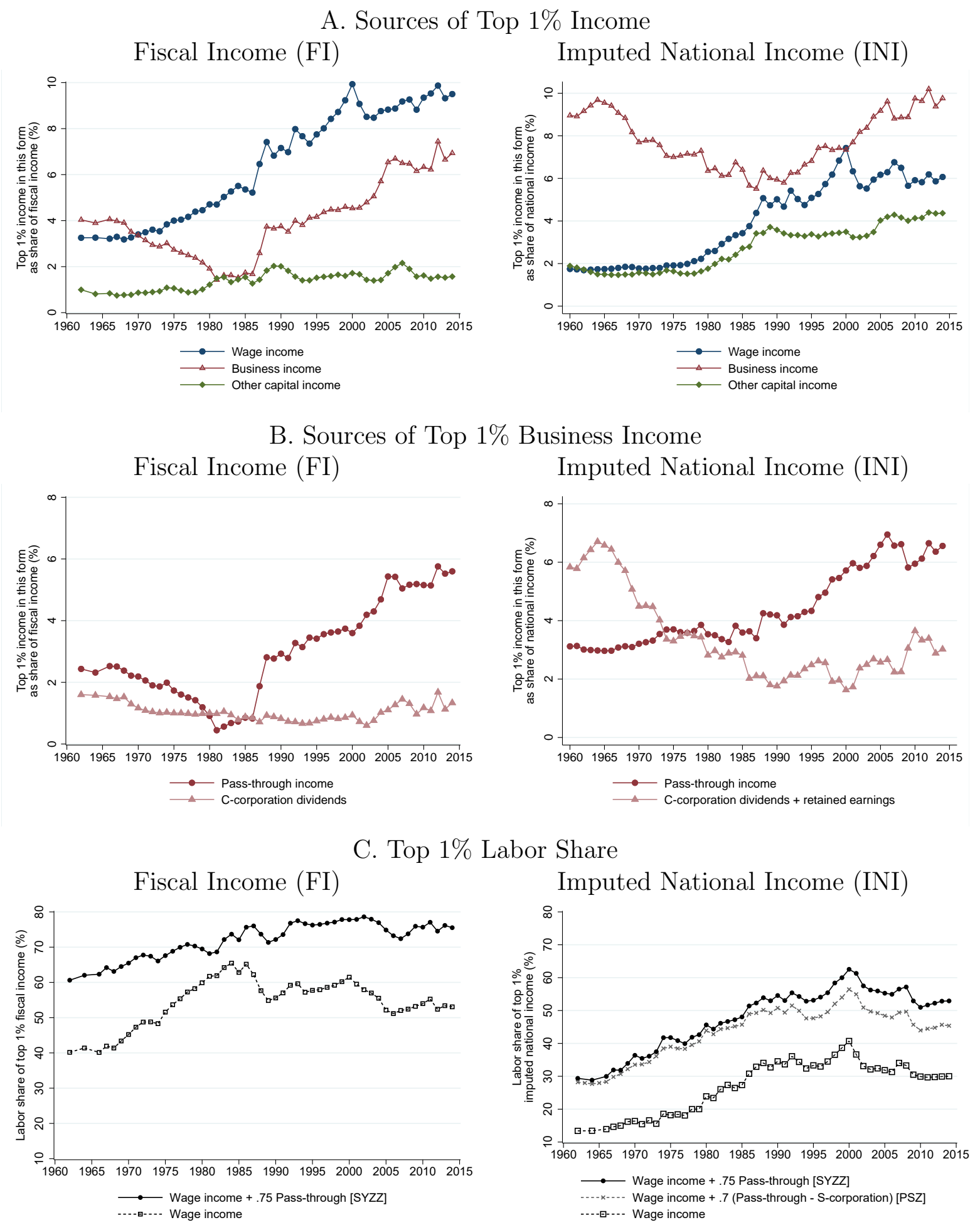

Notes: This figure uses our top incomes data to show the relative importance of different income sources for the evolution of top income shares. See the notes to Figure 1 for definitions. 
Figure 10: Why is Entrepreneurial Income Rising? Productivity, Scale, or Redistribution

\section{A. Value Added and Entrepreneurial Income per Worker}

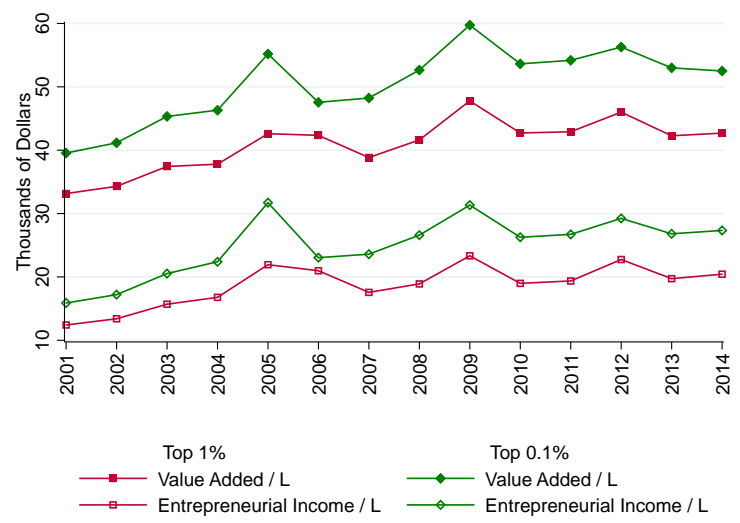

\section{Decomposing Entrepreneurial} Income Growth

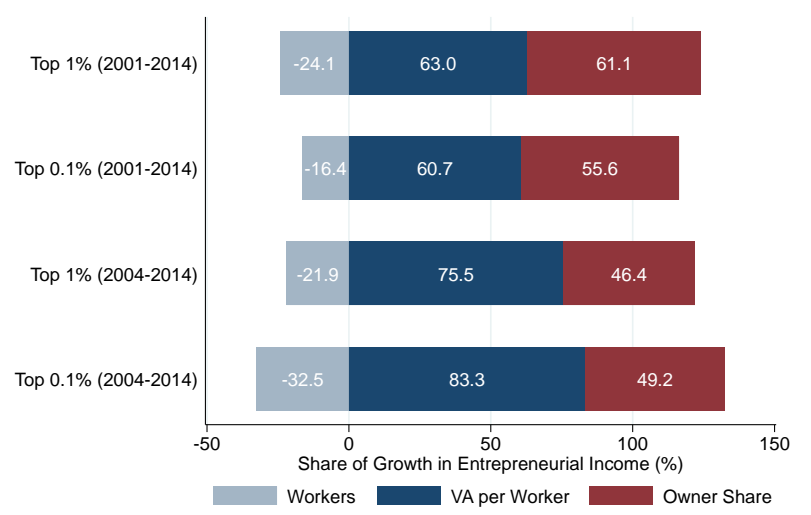

B. Pass-through Employment Adjusted for Org. Form Changes
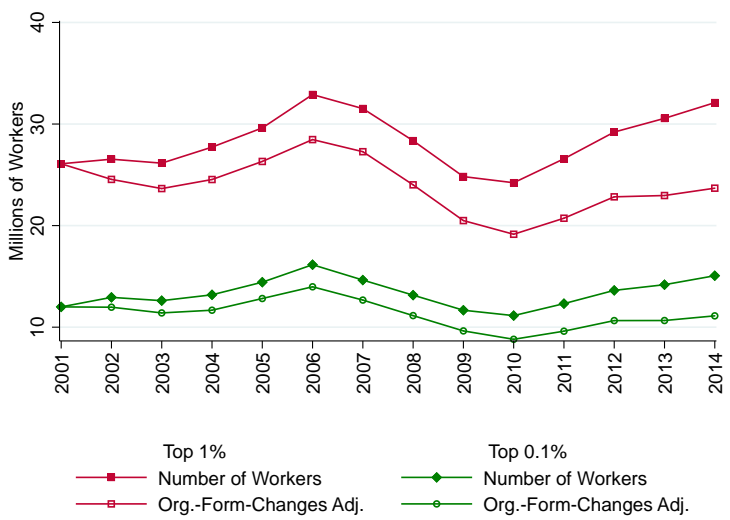

D. Falling Wages and Rising Entrepreneurial Income
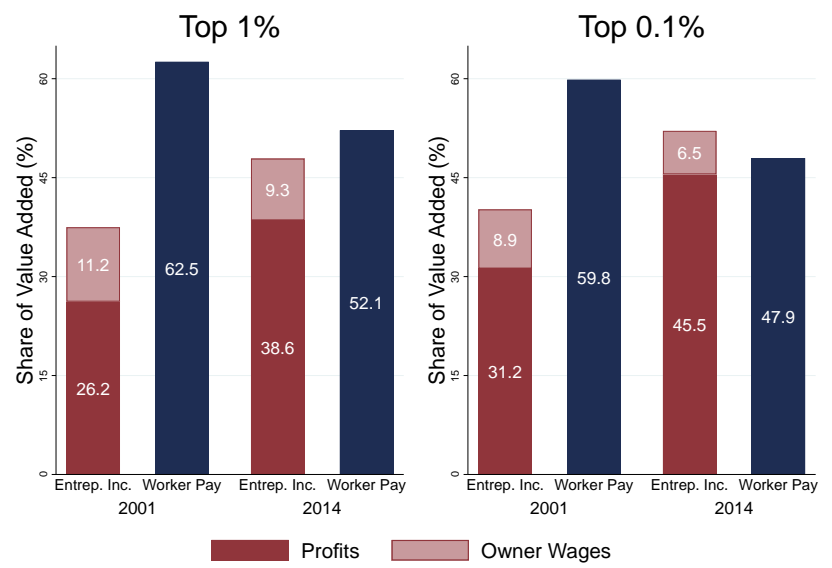

Notes: Panel A uses our linked-firm-owner data to plot aggregate value added per worker and entrepreneurial income (equal to pass-through income plus owner wages) per worker for top $1 \%$ and top $0.1 \%$ pass-through businesses. Panel B plots pass-through employment (the annual number of $\mathrm{W}-2 \mathrm{~s}$ ) for top $1 \%$ and top $0.1 \%$ pass-throughs. The Org.-Form-Changes Adjusted series reduces the main series' growth by a factor equal to the pass-through sales share of total business sales in 2001 divided by the contemporaneous pass-through sales share. For 2014, this procedure reduces growth since 2001 by $24 \%$. Panel $\mathrm{C}$ uses equation (3) to decompose the total growth in top entrepreneurial income into contributions from growth in value added per worker, in the owner share of value added, and in total employment adjusted for organizational form changes. Results for total growth from 2001 to 2014 and from 2004 to 2014 are shown. Panel D shows the distribution of value added accruing to owners (in the form of profits and owner wages) and to non-owner workers (in the form of wages) for top-owned firms in 2001 and in 2014. 
Table 1: Summary Statistics on Pass-throughs and Their Owners (2001-2014)

\section{A. Firm Summary Statistics}

Sales

Profits

Profit margin

Employees

Employees | Employees $>0$

Number of owners

Number of owners, S-corp only

Number of owners, Pship only

Sales per worker

Profits per worker

Profits per owner

Entrepreneurial income

Entrep. income per owner

Entrep. income per worker

Entrep. income / profit

Entrep. income / sales

Number of firm-years

\begin{tabular}{cccc}
\multicolumn{4}{c}{ A. All Firms } \\
\hline Mean & p10 & p50 & p90 \\
\hline 1,809 & 13 & 229 & 2,487
\end{tabular}

$\begin{array}{cccc}31 & -30 & 12 & 194 \\ 0.05 & -0.29 & 0.05 & 0.48\end{array}$

$\begin{array}{llll}1,347 & 0 & 51 & 1,119\end{array}$

$\begin{array}{llll}12.9 & 0.0 & 1.0 & 23.6\end{array}$

$\begin{array}{llll}21.9 & 1.0 & 5.0 & 40.1\end{array}$

$\begin{array}{llll}2.3 & 1.0 & 1.5 & 3.0\end{array}$

$\begin{array}{llll}1.6 & 1.0 & 1.0 & 2.4\end{array}$

$\begin{array}{llll}4.4 & 1.0 & 2.0 & 4.0\end{array}$

$\begin{array}{llll}196.1 & 20.6 & 86.5 & 363.3\end{array}$

$\begin{array}{llll}16.1 & -6.3 & 3.9 & 49.1\end{array}$

$\begin{array}{llll}-27.6 & -19.3 & 8.0 & 127.3\end{array}$

$\begin{array}{llll}144 & -19 & 28 & 291\end{array}$

$\begin{array}{llll}77.5 & -11.9 & 18.7 & 192.3\end{array}$

$\begin{array}{llll}33.8 & -2.2 & 11.8 & 82.2\end{array}$

$\begin{array}{llll}1.50 & 0.43 & 1 & 3.22\end{array}$

$\begin{array}{llll}0.12 & -0.31 & 0.11 & 0.64\end{array}$

$58,933,472$
B. Firms with Top 1-0.1\% Owner

\begin{tabular}{cccc} 
Mean & p10 & p50 & p90 \\
\hline 3,660 & 20 & 946 & 8,309
\end{tabular}

$\begin{array}{llll}3,660 & -40 & -946 & 8,309\end{array}$

$\begin{array}{llll}0.12 & -0.12 & 0.08 & 0.59\end{array}$

$\begin{array}{llll}1,997 & 4 & 291 & 3,852\end{array}$

$\begin{array}{llll}27.7 & 0.0 & 3.7 & 60.7\end{array}$

$\begin{array}{lll}43.3 & 1.5 & 13.0\end{array}$

$\begin{array}{lll}2.8 & 1.0 & 2.0\end{array}$

$2.2 \quad 1.0 \quad 1.2$

$\begin{array}{lll}4.0 & 1.0 & 2.0\end{array}$

$314.0 \quad 26.5 \quad 134.1$

$\begin{array}{lll}39.5 & -3.5 & 9.8\end{array}$

$131.8-18.5 \quad 42.0$

$\begin{array}{lll}338 & -23 & 162\end{array}$

$\begin{array}{lll}190.0 & -10.2 & 79.9\end{array}$

$\begin{array}{lll}65.9 & -0.7 & 21.5\end{array}$

$\begin{array}{lll}1.68 & 0.57 & 1\end{array}$

$\begin{array}{lll}0.18 & -0.18 & 0.15\end{array}$

$7,379,599$
C. Firms with Top $0.1 \%$ Owner

\begin{tabular}{cccc} 
Mean & p10 & p50 & p90 \\
\hline 17,496 & 19 & 1,772 & 34,668
\end{tabular}

$\begin{array}{llll}1.602 & -145 & 127 & 3.302\end{array}$

$\begin{array}{llll}0.13 & -0.16 & 0.09 & 0.71\end{array}$

$\begin{array}{llll}17,696 & 20 & 1,223 & 21,314\end{array}$

$\begin{array}{llll}74.3 & 0.0 & 1.6 & 141.3\end{array}$

$\begin{array}{llll}140.0 & 2.5 & 32.9 & 249.3\end{array}$

$\begin{array}{llll}14.2 & 1.0 & 2.0 & 12.0\end{array}$

$\begin{array}{llll}3.4 & 1.0 & 2.0 & 6.1\end{array}$

$\begin{array}{llll}27.8 & 1.0 & 3.0 & 21.2\end{array}$

$\begin{array}{llll}761.8 & 22.9 & 164.9 & 1.094 .0\end{array}$

$\begin{array}{llll}122.0 & -10.7 & 8.8 & 177.5\end{array}$

$620.2 \quad-48.7 \quad 41.2 \quad 1,623.0$

$\begin{array}{cccc}\cdot & -96 & 143 & \cdot \\ 634.2 & -31.2 & 45.7 & 1,813.0\end{array}$

$\begin{array}{llll}155.6 & -6.0 & 13.9 & 246.6\end{array}$

$\begin{array}{llll}1.24 & 0.40 & 1 & 1.60\end{array}$

$\begin{array}{llll}0.15 & -0.36 & 0.10 & 0.87\end{array}$

$2,464,603$

\section{B. Owner Summary Statistics}

Income

Age

Number of firms owned

Wage income

Pass-through income

Entrepreneurial income

Pthru income / entrep. income

Wage income / income

Entrep. income / income

Entrep. inc. / inc., S-corp owners only

Entrep. inc. / inc., Pship owners only

Business income / income

Only earns passive income

Number of owner-years
A. All Owners

$\begin{array}{llll}\text { Mean } & \text { p10 } & \text { p50 } & \text { p90 }\end{array}$

\begin{tabular}{cccc}
\hline 235 & 13 & 98 & 476 \\
51.1 & 34.3 & 50.7 & 69.6
\end{tabular}

$\begin{array}{cccc}51.1 & 34.3 & 50.7 & 69.6 \\ 1.3 & 1.0 & 1.0 & 2.0\end{array}$

$\begin{array}{llll}76 & 0 & 21 & 165\end{array}$

$\begin{array}{llll}51 & -12 & 3 & 113\end{array}$

$\begin{array}{llll}75 & -8 & 8 & 181\end{array}$

$\begin{array}{llll}0.81 & 0.19 & 1 & 1\end{array}$

$\begin{array}{llll}0.63 & 0 & 0.20 & 0.95\end{array}$

$\begin{array}{llll}2.07 & -0.08 & 0.12 & 0.99\end{array}$

$\begin{array}{llll}0.73 & -0.08 & 0.39 & 1.01\end{array}$

$\begin{array}{llll}3.85 & -0.08 & 0.01 & 0.79\end{array}$

$\begin{array}{llll}0.22 & -0.13 & 0.10 & 0.92\end{array}$

0.11

$\begin{array}{cc}0 & 0 \\ 108,575,625\end{array}$
B. Top 1-0.1\% Owners

\begin{tabular}{cccc}
\hline Mean & p10 & p50 & p90 \\
\hline 655 & 393 & 571 & 1,089
\end{tabular}

$\begin{array}{llll}52.4 & 38.9 & 51.9 & 67.4\end{array}$

$\begin{array}{lll}1.5 & 1.0 & 1.0\end{array}$

$\begin{array}{lll}203 & 0 & 123\end{array}$

$\begin{array}{lll}166 & -6 & 51\end{array}$

$\begin{array}{lll}231 & -3 & 108\end{array}$

$0.85 \quad 0.35 \quad 1$

$\begin{array}{lll}0.32 & 0 & 0.21\end{array}$

$\begin{array}{lll}0.35 & -0.01 & 0.19\end{array}$

$\begin{array}{lll}0.50 & 0 & 0.51\end{array}$

$\begin{array}{lll}0.21 & -0.01 & 0.0\end{array}$

$\begin{array}{lll}0.37 & 0 & 0.35\end{array}$

$\begin{array}{ccc}0.11 & 0 & 0 \\ & & 11,793,249\end{array}$

2.8
537

537

530

667

1

0.89

1
0.90

0.91

0.87
C. Top $0.1 \%$ Owners

$\begin{array}{cccc}\text { Mean } & \text { p10 } & \text { p50 } & \text { p90 } \\ 4,687 & 1,559 & 2,430 & 7,879\end{array}$

$\begin{array}{llll}54.5 & 40.6 & 53.9 & 70.4\end{array}$

$\begin{array}{llll}2.2 & 1.0 & 1.0 & 4.5\end{array}$

$\begin{array}{llll}932 & 0 & 226 & 2,256\end{array}$

$\begin{array}{llll}1,074 & -15 & 162 & 2,638\end{array}$

$\begin{array}{ccc}0.91 & 0.70 & 1\end{array}$

$\begin{array}{llll}0.24 & 0 & 0.08 & 0.89\end{array}$

$\begin{array}{llll}0.32 & 0 & 0.09 & 0.96\end{array}$

$\begin{array}{llll}0.48 & 0 & 0.49 & 0.98\end{array}$

$\begin{array}{llll}0.18 & -0.01 & 0 & 0.87\end{array}$

$\begin{array}{llll}0.47 & 0 & 0.57 & 0.94\end{array}$

$\begin{array}{rrr}0.07 & 0 & 0\end{array}$ 
Notes to Table 1: This table presents summary statistics for our linked-firm-owner data, comprising pass-through firms linked to owners $2001-2014$. Dollar values are in thousands of 2014 dollars. The main sample comprises 109M firm-owner-year observations with positive sales and non-zero profits. Panel A pools distinct firm-year observations. Panel B pools distinct owner-year observations. All statistics are unweighted, unless otherwise specified. All variables are annual and are available in all years. Year refers to calendar year, which by law is also each pass-through's fiscal year. Sales is the firm's operating revenue (gross sales minus returns) as listed on the firm tax return. Passively earned income (e.g., interest on bank deposits) is excluded. Profits is the firm's ordinary business income, equal to operating revenue minus costs as listed on the firm tax return. Profit margin equals profits divided by sales. Employees and number of workers equals the number of individuals who received a W-2 from the firm that year. A quantity per worker equals the quantity divided by the number of workers. Entrepreneurial income equals pass-through income plus W-2 wages paid to pass-through owners. Income is short for fiscal income and is the main income concept used in Piketty and Saez (2003) and equals Form 1040 total income minus Form 1040 capital gains minus Form 1040 unemployment compensation minus Form 1040 taxable social security benefits. Age is age as of December 31, based on year of birth from Social Security records housed alongside tax records. An owner is a top 1-0.1\% owner or a top 0.1\% owner if her fiscal income lies in the top $1 \%$ but not the top $0.1 \%$ or the top $0.1 \%$ of all tax units in the year, respectively. Wage income equals W-2 income. Pass-through income equals the owner's share of the profits from all pass-throughs she owns. Business income is total pass-through business income and equals total Form 1040, Schedule E income. An owner's pass-through income is active if the owner reports she materially participates in the operations of any of her pass-through businesses and is passive otherwise. For these summary statistics, two variables are winsorized in the underlying data at the unweighted first percentile and the unweighted ninety-ninth percentile of the annual distributions: Entrep. income / profit, and Business income / income. Two variables are winsorized below at -1 and above at 1: Profit margin, Entrep. income/ sales, and Entrep. income / value added. Assets is set to missing for the very few observations in which assets are over one trillion. 
Table 2: Industrial Composition of Million-dollar-owned Pass-through and All C-corporation Profits (2014)

\begin{tabular}{|c|c|c|c|c|c|c|c|c|c|}
\hline & \multirow[b]{2}{*}{ Industry (NAICS) } & \multirow{2}{*}{$\frac{\text { Top Passthru }}{\text { Profit }(\$ M)}$} & \multicolumn{2}{|c|}{ C-corp } & & \multirow[b]{2}{*}{ Industry (NAICS) } & \multirow{2}{*}{$\frac{\text { C-corp }}{\text { Profit }(\$ M)}$} & \multicolumn{2}{|c|}{ Top Passthru } \\
\hline & & & Rank & Profit $(\$ M)$ & & & & Rank & Profit $(\$ M)$ \\
\hline 1 & Legal svc (5411) & 28643 & 144 & 477 & 1 & Petroleum/coal products mfg. (3241) & 98696 & 109 & 441 \\
\hline 2 & Other financial investment actvty (5239) & 28207 & 13 & 17712 & 2 & Pharmaceutical/medicine mfg. (3254) & 63295 & 112 & 403 \\
\hline 3 & Other professional/technical svc (5419) & 8196 & 248 & -480 & 3 & Nondepository credit intrmd (5222) & 46573 & 26 & 1957 \\
\hline 4 & Offices of physicians (6211) & 8018 & 250 & -727 & 4 & Other telecommunications (5179) & 35288 & 254 & 2 \\
\hline 5 & Automobile dealers (4411) & 6712 & 64 & 3121 & 5 & Computer/peripheral equipment mfg. (3341) & 33250 & 106 & 448 \\
\hline 6 & Oil/gas extraction (2111) & 6290 & 12 & 18375 & 6 & Other general merchandise stores (4529) & 27027 & 139 & 283 \\
\hline 7 & Management/techncl consulting svc (5416) & 5940 & 56 & 4388 & 7 & Druggists' goods merch whlsl (4242) & 25191 & 94 & 497 \\
\hline 8 & Activities related to real estate $(5313)$ & 5209 & 110 & 1012 & 8 & Aerospace product/parts mfg. (3364) & 22997 & 136 & 290 \\
\hline 9 & Computer sys design/related svc (5415) & 4771 & 253 & -5446 & 9 & Semiconductor/electronic compnt mfg. (3344) & 21460 & 69 & 709 \\
\hline 10 & Other specialty trade cntrctr (2389) & 4730 & 123 & 769 & 10 & Motor vehicle mfg. (3361) & 20521 & 179 & 152 \\
\hline 11 & Misc. durable goods merch whlsl (4239) & 3853 & 98 & 1419 & 11 & Soap, cleaning compound,/toiletry mfg. (3256) & 20326 & 163 & 189 \\
\hline 12 & Other fabricated metal prod mfg. (3329) & 3754 & 37 & 7636 & 12 & Oil/gas extraction (2111) & 18375 & 6 & 6290 \\
\hline 13 & Other miscellaneous mfg. (3399) & 3328 & 76 & 2300 & 13 & Other financial investment actvty (5239) & 17712 & 2 & 28207 \\
\hline 14 & Accounting/bookkeeping svc (5412) & 3129 & 59 & 3741 & 14 & Grocery/related product whlsl (4244) & 15945 & 35 & 1519 \\
\hline 15 & Insurance agencies/brokerages (5242) & 2934 & 44 & 6167 & 15 & Software publishers (5112) & 15010 & 99 & 472 \\
\hline 16 & Architectural/engineering svc (5413) & 2933 & 70 & 2802 & 16 & Ag., constr,/mining machinery mfg. (3331) & 14814 & 105 & 452 \\
\hline 17 & Nonresidential building constr (2362) & 2899 & 140 & 555 & 17 & Other information sve (5191) & 14684 & 70 & 707 \\
\hline 18 & Building equipment cntrctr (2382) & 2891 & 97 & 1442 & 18 & Activities related to credit intrmd (5223) & 14503 & 142 & 266 \\
\hline 19 & Residential building constr (2361) & 2742 & 55 & 4489 & 19 & Restaurants (7225) & 14137 & 20 & 2690 \\
\hline 20 & Restaurants (7225) & 2690 & 19 & 14137 & 20 & Basic chemical mfg. (3251) & 14136 & 86 & 550 \\
\hline 21 & Other heavy constr $(2379)$ & 2669 & 240 & -109 & 21 & Health/personal care stores (4461) & 13448 & 33 & 1594 \\
\hline 22 & Misc. nondrbl gds merch whlsl (4249) & 2440 & 54 & 4494 & 22 & Traveler acmdtn (7211) & 12761 & 45 & 1229 \\
\hline 23 & Security contracts broker (5231) & 2268 & 30 & 10530 & 23 & Building material/supp dealers (4441) & 12758 & 61 & 902 \\
\hline 24 & Plastics product mfg. (3261) & 2140 & 119 & 799 & 24 & Converted paper product mfg. (3222) & 11287 & 90 & 523 \\
\hline 25 & Machinery/supply merch whlsl (4238) & 1958 & 33 & 9022 & 25 & Beverage mfg. (3121) & 11274 & 63 & 871 \\
\hline 26 & Nondepository credit intrmd (5222) & 1957 & 3 & 46573 & 26 & Motion picture/video industries (5121) & 11253 & 92 & 507 \\
\hline 27 & Indie artists, writers, performers (7115) & 1915 & 229 & -25 & 27 & Grocery stores $(4451)$ & 11005 & 53 & 1035 \\
\hline 28 & Other investment pools/funds (5259) & 1854 & 72 & 2509 & 28 & Depository credit intrmd (5221) & 10948 & 55 & 976 \\
\hline 29 & Support actvty for mining (2131) & 1820 & 41 & 6480 & 29 & Radio/television broadcasting (5151) & 10920 & 148 & 253 \\
\hline 30 & Advertising, pr,/related svc (5418) & 1792 & 90 & 1748 & 30 & Security contracts broker (5231) & 10530 & 23 & 2268 \\
\hline
\end{tabular}

Notes: This table presents statistics on the level of million-dollar-owned pass-through profits and total C-corporation profits in 2014 by 4-digit industry. The rows are sorted by the level of top pass-through profits on the left and C-corporation profits on the right. These statistics apportion pass-through profits pro rata to owners and then aggregate those apportioned profits by 4-digit industry. Rank columns indicate the rank of that 4-digit industry within a particular group of firms. Profits columns indicate the level of profits in millions of 2014 dollars. 
Table 3: Industrial Composition of Pass-through Profits (Top 1-0.1\% vs. Top 0.1\%, 2014)

\begin{tabular}{|c|c|c|c|c|c|}
\hline & S-corporation Industry (NAICS) & Top $1-0.1 \%$ Profit $(\$ M)$ & & S-corporation Industry (NAICS) & Top $0.1 \%$ Profit $(\$ M)$ \\
\hline 1 & Offices of physicians (6211) & 9063 & 1 & Other financial investment actvty (5239) & 5786 \\
\hline 2 & Other professional/technical svc (5419) & 4778 & 2 & Automobile dealers (4411) & 5176 \\
\hline 3 & Offices of dentists (6212) & 4317 & 3 & Oil/gas extraction (2111) & 4820 \\
\hline 4 & Other specialty trade cntrctr (2389) & 3893 & 4 & Other professional/technical svc (5419) & 4186 \\
\hline 5 & Legal svc (5411) & 3485 & 5 & Offices of physicians (6211) & 3621 \\
\hline 6 & Insurance agencies/brokerages (5242) & 2678 & 6 & Computer sys design/related svc (5415) & 3206 \\
\hline 7 & Computer sys design/related svc (5415) & 2662 & 7 & Management/techncl consulting svc (5416) & 3185 \\
\hline 8 & Architectural/engineering svc (5413) & 2642 & 8 & Other specialty trade cntrctr (2389) & 3086 \\
\hline 9 & Building equipment cntrctr (2382) & 2595 & 9 & Legal svc (5411) & 2847 \\
\hline 10 & Restaurants $(7225)$ & 2421 & 10 & Misc. durable goods merch whlsl (4239) & 2836 \\
\hline 11 & Management/techncl consulting svc (5416) & 2196 & 11 & Other fabricated metal prod mfg. (3329) & 2727 \\
\hline 12 & Nonresidential building constr (2362) & 1906 & 12 & Other miscellaneous mfg. (3399) & 2477 \\
\hline 13 & Offices of other health practitioners (6213) & 1886 & 13 & Activities related to real estate (5313) & 2286 \\
\hline 14 & Misc. durable goods merch whlsl (4239) & 1684 & 14 & Other heavy constr (2379) & 2248 \\
\hline \multirow[t]{2}{*}{15} & Other fabricated metal prod mfg. (3329) & 1670 & 15 & Nonresidential building constr (2362) & 1940 \\
\hline & Partnership Industry (NAICS) & Top 1-0.1\% Profit $(\$ M)$ & & Partnership Industry (NAICS) & Top $0.1 \%$ Profit $(\$ M)$ \\
\hline 1 & Legal svc (5411) & 21320 & 1 & Other financial investment actvty (5239) & 20220 \\
\hline 2 & Offices of physicians (6211) & 5923 & 2 & Legal sve (5411) & 18200 \\
\hline 3 & Accounting/bookkeeping svc (5412) & 5316 & 3 & Activities related to real estate (5313) & 2534 \\
\hline 4 & Other financial investment actvty (5239) & 3395 & 4 & Other professional/technical svc (5419) & 2254 \\
\hline 5 & Other professional/technical svc (5419) & 1641 & 5 & Oil/gas extraction (2111) & 2035 \\
\hline 6 & Outpatient care centers $(6214)$ & 1449 & 6 & Management/techncl consulting svc (5416) & 1637 \\
\hline 7 & Activities related to real estate $(5313)$ & 1357 & 7 & Security contracts broker (5231) & 1485 \\
\hline 8 & Management/techncl consulting svc (5416) & 1263 & 8 & Other investment pools/funds (5259) & 1372 \\
\hline 9 & Oil/gas extraction (2111) & 1139 & 9 & Accounting/bookkeeping svc (5412) & 1166 \\
\hline 10 & Restaurants (7225) & 694 & 10 & Offices of physicians (6211) & 1026 \\
\hline 11 & Offices of other health practitioners (6213) & 670 & 11 & Automobile dealers (4411) & 693 \\
\hline 12 & Offices of dentists (6212) & 574 & 12 & Residential building constr (2361) & 689 \\
\hline 13 & Insurance agencies/brokerages (5242) & 573 & 13 & Lessors of real estate (5311) & 685 \\
\hline 14 & Computer sys design/related svc (5415) & 563 & 14 & Computer sys design/related svc (5415) & 585 \\
\hline 15 & Architectural/engineering svc (5413) & 550 & 15 & Fruit/tree nut farming (1113) & 482 \\
\hline
\end{tabular}

Notes: This table presents statistics on the level of S-corporation and partnership profits for top earners in 2014 by 4 -digit industry. We present statistics for two groups of firms: firms owned by the top 1-0.1\% and firms owned by the top 0.1\%. The rows are sorted by the level of firm profits for firms owned by the top $0.1 \%$ and top $1-0.1 \%$, respectively. These statistics apportion profits pro rata to owners in either the top $0.1 \%$ or the top $1-0.1 \%$ and then aggregate those apportioned profits by 4-digit industry. Profits columns indicate the level of profits in millions of 2014 dollars. 
Table 4: Impact of Owner Deaths and Retirements on Firm Profits

\begin{tabular}{|c|c|c|c|c|c|c|c|c|c|}
\hline \multirow[b]{4}{*}{ A. Owner Deaths } & \multicolumn{7}{|c|}{ Million-Dollar-Earning Owners } & $\begin{array}{l}\text { Top-1\% } \\
\text { Owners }\end{array}$ & $\begin{array}{c}\text { Top- } 0.1 \% \\
\text { Owners }\end{array}$ \\
\hline & \multirow{3}{*}{$\begin{array}{c}\text { Profits per } \\
\text { pre-period worker } \\
\text { (\$/worker) } \\
(1) \\
\end{array}$} & \multirow{3}{*}{$\begin{array}{c}\text { Firm } \\
\text { survival } \\
(\mathrm{pp}) \\
(2) \\
\end{array}$} & \multicolumn{5}{|c|}{ Profits per pre-period worker (\$/worker) } & \multicolumn{2}{|c|}{$\begin{array}{l}\text { Profits per pre-period } \\
\text { worker (\$/worker) }\end{array}$} \\
\hline & & & (3) & (4) & $(5)$ & (6) & $(7)$ & & (9) \\
\hline & & & & & & & & & \\
\hline Impact & $\begin{array}{l}-20,591 \\
(5,886)\end{array}$ & $\begin{array}{l}-0.198 \\
(0.017)\end{array}$ & $\begin{array}{c}-13,252 \\
(7,074)\end{array}$ & $\begin{array}{l}-13,843 \\
(6,763)\end{array}$ & $\begin{array}{r}-25,960 \\
(9,096)\end{array}$ & $\begin{array}{c}5,205 \\
(4,450)\end{array}$ & $\begin{array}{r}-23,900 \\
(6,896)\end{array}$ & $\begin{array}{l}-12,920 \\
(1,831)\end{array}$ & $\begin{array}{c}-29,543 \\
(10,582)\end{array}$ \\
\hline Surviving firms only & & & $\mathrm{X}$ & & & & & & \\
\hline Minority owner & & & & $\mathrm{X}$ & & & & & \\
\hline Majority owner & & & & & $\mathrm{X}$ & & & & \\
\hline Death before 65 & $\mathrm{X}$ & $\mathrm{X}$ & $\mathrm{X}$ & $\mathrm{X}$ & $\mathrm{X}$ & & $\mathrm{X}$ & $\mathrm{X}$ & $\mathrm{X}$ \\
\hline Death after 75 & & & & & & $\mathrm{X}$ & & & \\
\hline S-corporations only & & & & & & & $\mathrm{X}$ & & \\
\hline Observations & 581,508 & 581,508 & 236,241 & 208,107 & 373,401 & 57,060 & 519,804 & $2,609,973$ & 194,787 \\
\hline Owner deaths & 765 & 765 & 390 & 339 & 426 & 725 & 658 & 2,436 & 435 \\
\hline$R^{2}$ & 0.003 & 0.072 & 0.001 & 0.001 & 0.006 & 0.000 & 0.004 & 0.004 & 0.005 \\
\hline Mean of counterfactual firms & 38,401 & 0.881 & 41,813 & 36,919 & 39,580 & 18,494 & 38,886 & 27,258 & 48,221 \\
\hline Dying owners ownership \% & $65.7 \%$ & $65.7 \%$ & $57.7 \%$ & $39.4 \%$ & $86.7 \%$ & $59.6 \%$ & $68.5 \%$ & $65.0 \%$ & $66.4 \%$ \\
\hline Preferred percentage impact & $-81.6 \%$ & $-34.2 \%$ & $-55.0 \%$ & $-95.2 \%$ & $-75.6 \%$ & $47.2 \%$ & $-89.7 \%$ & $-72.9 \%$ & $-92.3 \%$ \\
\hline \multicolumn{10}{|l|}{ B. Owner Retirements } \\
\hline Impact & $\begin{array}{l}-37,210 \\
(4,000)\end{array}$ & $\begin{array}{l}-0.263 \\
(0.007)\end{array}$ & $\begin{array}{l}-23,192 \\
(5,003)\end{array}$ & $\begin{array}{l}-29,483 \\
(7,296)\end{array}$ & $\begin{array}{r}-40,109 \\
(4,771)\end{array}$ & & $\begin{array}{c}-39,774 \\
(4,051)\end{array}$ & $\begin{array}{r}-17,150 \\
(1,027)\end{array}$ & $\begin{array}{r}-45,861 \\
(7,286)\end{array}$ \\
\hline Surviving firms only & & & $\mathrm{X}$ & & & & & & \\
\hline Minority owner & & & & $\mathrm{X}$ & & & & & \\
\hline Majority owner & & & & & $\mathrm{X}$ & & & & \\
\hline S-corporations only & & & & & & & $\mathrm{X}$ & & \\
\hline Observations & 442,566 & 442,566 & 214,722 & 116,064 & 326,502 & & 422,370 & $1,432,179$ & 255,897 \\
\hline Owner retirements & 5,312 & 5,312 & 2,969 & 1,449 & 3,863 & & 4,974 & 16,548 & 3,176 \\
\hline$R^{2}$ & 0.004 & 0.107 & 0.002 & 0.003 & 0.005 & & 0.005 & 0.005 & 0.003 \\
\hline Mean of counterfactual firms & 59,996 & 0.924 & 67,044 & 52,344 & 62,866 & & 60,464 & 37,780 & 84,573 \\
\hline Retiring owners ownership \% & $75.2 \%$ & $75.2 \%$ & $75.8 \%$ & $40.1 \%$ & $88.3 \%$ & & $76.6 \%$ & $76.2 \%$ & $75.6 \%$ \\
\hline Preferred percentage impact & $-82.5 \%$ & $-37.9 \%$ & $-45.6 \%$ & $-140.4 \%$ & $-72.2 \%$ & & $-85.9 \%$ & $-59.6 \%$ & $-71.7 \%$ \\
\hline
\end{tabular}

Notes: This table estimates the impact of an owner "exit," embodied in an owner death or retirement, on firm performance four years after the event. Panel A uses the owner deaths sample to analyze the impact of owner deaths on firm performance four years after owner death relative to one year before owner death, relative to the matched counterfactual firms. Columns 1-2 report the right-most coefficients plotted in Figures 5A-B. See the notes to that figure for details. Column 3 repeats Column 2 on the subset of matched pairs of owner-death firms and counterfactual firms that survived four years after the owner death. Column 4 repeats Column 2 on the subset of matched pairs where the dying owner had $50 \%$ or less ownership in the owner-death firm; Column 5 repeats Column 2 on all other pairs. Column 6 repeats Column 2 in an identically constructed sample of matched owner-death firms that is based on owners who died at age 75 or greater. Column 7 repeats Column 1 in an identically constructed sample of matched owner-death Scorporations. The outcome mean of counterfactual firms is the weighted mean four years after owner death (see the text for the weight). The ownership share of dying owners is measured in the year before owner death. Panel B repeats Panel A for the subset of owner-retirement and counterfactual firms. See Sections 3.1 and 3.2 for more details. 